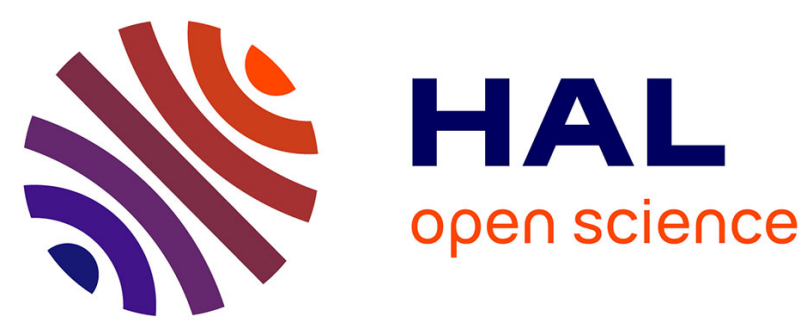

\title{
Atmospheric pressure plasma spraying of silane-based coatings targeting whey protein fouling and bacterial adhesion management
}

Sawsen Zouaghi, Thierry Six, Séverine Bellayer, Yannick Coffinier, Marwan Abdallah, Nour-Eddine Chihib, Christophe Andre, Guillaume Delaplace, Maude Jimenez

\section{To cite this version:}

Sawsen Zouaghi, Thierry Six, Séverine Bellayer, Yannick Coffinier, Marwan Abdallah, et al.. Atmospheric pressure plasma spraying of silane-based coatings targeting whey protein fouling and bacterial adhesion management. Applied Surface Science, 2018, 455, pp.392-402. 10.1016/j.apsusc.2018.06.006 . hal-02321911

\section{HAL Id: hal-02321911 \\ https://hal.science/hal-02321911}

Submitted on 21 Oct 2019

HAL is a multi-disciplinary open access archive for the deposit and dissemination of scientific research documents, whether they are published or not. The documents may come from teaching and research institutions in France or abroad, or from public or private research centers.
L'archive ouverte pluridisciplinaire HAL, est destinée au dépôt et à la diffusion de documents scientifiques de niveau recherche, publiés ou non, émanant des établissements d'enseignement et de recherche français ou étrangers, des laboratoires publics ou privés. 


\section{Accepted Manuscript}

Full Length Article

Atmospheric Pressure Plasma Spraying of Silane-Based Coatings Targeting Whey Protein Fouling and Bacterial Adhesion Management

Sawsen Zouaghi, Thierry Six, Séverine Bellayer, Yannick Coffinier, Marwan Abdallah, Nour-Eddine Chihib, Christophe. André, Guillaume Delaplace,

Maude Jimenez

PII: S0169-4332(18)31573-3

DOI: https://doi.org/10.1016/j.apsusc.2018.06.006

Reference:

APSUSC 39514

To appear in:

Applied Surface Science

Received Date:

20 February 2018

Revised Date:

4 May 2018

Accepted Date:

1 June 2018

Please cite this article as: S. Zouaghi, T. Six, S. Bellayer, Y. Coffinier, M. Abdallah, N-E. Chihib, Christophe. André, G. Delaplace, M. Jimenez, Atmospheric Pressure Plasma Spraying of Silane-Based Coatings Targeting Whey Protein Fouling and Bacterial Adhesion Management, Applied Surface Science (2018), doi: https://doi.org/10.1016/ j.apsusc.2018.06.006

This is a PDF file of an unedited manuscript that has been accepted for publication. As a service to our customers we are providing this early version of the manuscript. The manuscript will undergo copyediting, typesetting, and review of the resulting proof before it is published in its final form. Please note that during the production process errors may be discovered which could affect the content, and all legal disclaimers that apply to the journal pertain. 


\section{Atmospheric Pressure Plasma Spraying of Silane-Based Coatings Targeting Whey Protein Fouling and Bacterial Adhesion Management.}

Sawsen Zouaghi ${ }^{1}$, Thierry Six ${ }^{1,2}$, Séverine Bellayer ${ }^{1}$,Yannick Coffinier ${ }^{3}$, Marwan Abdallah ${ }^{1}$, Nour-Eddine Chihib ${ }^{1}$, Christophe. André ${ }^{1,4}$, Guillaume Delaplace ${ }^{1,4}$, Maude Jimenez $^{1 *}$

${ }^{1}$ Univ. Lille, UMR 8207 - UMET - Unité Matériaux et Transformations, F-59000 Lille, France

${ }^{2}$ INRA, F-59000 Lille, France

${ }^{3}$ Institute of Electronics, Microelectronics and Nanotechnology, Univ. Lille, UMR 8520 - IEMN, F-59000 Lille, France

${ }^{4}$ Hautes Etudes d'Ingénieur, F-59000 Lille, France

*Corresponding Author: maude.jimenez@univ-lille1.fr

Sawsen Zouaghi

Thierry Six

Séverine Bellayer

Yannick Coffinier

Marwan Abdallah

Nour Eddine Chihib

Christophe André

Guillaume Delaplace sawsen.zouaghi@ed.univ-lille1.fr thierry.six@ lille.inra.fr severine.Bellayer@ensc-lille.fr yannick.Coffinier@univ-lille1.fr marwan.abdallah83@gmail.com nour-Eddine.Chihib@univ-lille1.fr christophe.andre@yncrea.fr guillaume.delaplace@lille.inra.fr 


\section{ABSTRACT}

This work aims at studying the impact of silane-based coatings, generated by atmospheric pressure plasma spraying (APPS) of a liquid precursor (hexamethydisiloxane - HMDSO), on dairy antifouling and antibacterial properties of food-grade $316 \mathrm{~L}$ stainless steel. The influence of the manufacturing parameters (precursor flow rate, nozzle-to-substrate distance and scanning speed) on the coatings properties was investigated using a wide range of characterization techniques (drop shape analysis, X-Ray Mappings, Scanning Electron Microscopy, FourierTransformed Infrared Spectroscopy, Atomic Force Microscopy). Coating's roughness in particular was shown to strongly increase when precursor flow rate increases. A pilot pasteurizer, fed with a model foulant solution (whey protein and calcium), allowed performing two consecutive industrial-like isothermal dairy fouling tests, revealing the promising anti-fouling properties of the HMDSO-coated steel. A fouling reduction of up to $90 \%$ compared to bare stainless steel was achieved after first cycle for all samples. The second fouling run allowed to select the best-performing sample, which kept the same antifouling properties as in the first test. Its mechanism of action was investigated, which revealed that a nanostructured, Si-O-Si rich surface was efficient to prevent isothermal dairy fouling. The adhesion of the pathogenic bacterium Staphylococcus aureus also proved to be impacted by this plasma coating, with a significant decrease of adhered cells (-30\% compared to native stainless steel).

Key-words: antifouling, atmospheric pressure plasma spraying, dairy pasteurization, silane, HMDSO 


\section{ACRONYMS}

AFM Atomic Force Microscopy

APPS Atmospheric pressure plasma spraying

FTIR Fourier-Transformed Infrared Spectroscopy

HMDSO Hexamethyldisiloxane

MF Model fluid

PHE Plate heat-exchanger

SEM Scanning Electron Microscopy

SFE $\quad$ Surface free energy

SS Stainless steel

TSB Tryptic Soy Broth

WCA Water contact angle

XPS X-Ray photoelectron spectroscopy

\section{SYMBOLS}

D Nozzle-to-substrate distance $(\mathrm{mm} / \mathrm{s})$

Q Precursor flow rate $(\mathrm{g} / \mathrm{h})$

v Scanning speed $(\mathrm{mm} / \mathrm{s})$

F\% Fouling weight percent compared to native stainless steel (-)

$\gamma \quad$ Interfacial or surface energy $(\mathrm{mN} / \mathrm{m})$

$\boldsymbol{\theta} \quad$ Contact angle $\left(^{\circ}\right)$ 


\section{INTRODUCTION}

Fouling is a worldwide, costly and eco-aggressive issue, common to all food industries, and particularly present in dairy thermal processing. Milk and its derivatives are indeed rich in thermosensitive biomolecules whose conformations and structures change under heating, leading to their accumulation on the stainless steel (SS) surfaces of industrial equipment. The resulting deposits need to be regularly removed to maintain process efficiency and thus ensure food safety. Those frequent clean-in-place procedures result in production loss and consume large amounts of water, chemicals and energy. Overall, it is estimated that around $80 \%$ of dairy production costs are related to fouling [1]. Control strategies for heat-induced dairy fouling and microbial adhesion are therefore urgently needed, as it would allow the development of less expensive and more eco-responsible thermal treatments [2].

During the past decades, a significant research effort has been made to better understand dairy fouling mechanisms and to develop preventive (antifouling) and/or remedial (fouling-release) solutions [3]. It is generally recognized that, under pasteurization conditions (fluid temperature below $100^{\circ} \mathrm{C}$ ), dairy deposits are mainly composed of soluble whey proteins (mainly $\beta$ lactoglobulin) and of calcium particles [4-7]. Previous works focusing on dairy fouling on a stainless steel (SS) surface demonstrated that unfolded protein deposits first during the early fouling steps [5] and that only unfolded protein takes part in deposit build-up, on the contrary to aggregated ones [8-10]. Heat induced fouling is also known to be a complex and multi-dependent phenomenon, impacted by the process parameters (e.g. temperature profiles $[6,10]$ and hydrodynamic features [6,11-14]) but also by the fluid's composition (e.g. calcium and protein ratio, ionic strength, $\mathrm{pH}[5,10,14-16])$ and by the surface properties (e.g. morphology, wettability, surface free energy [17-21]). 
Tuning the surface properties thus appears as a suitable route to reduce dairy fouling, as it allows modifying the interactions at the solid-liquid interface and consequently the protein adhesion. Several examples of surface modification targeting fouling control are available in the literature, although most of them target biomedical [22-25] and marine [26-29] fouling issues. Among them, atmospheric pressure plasma spraying (APPS) stands as a very versatile and easily upscalable process. It allows to functionalize a vast range of substrates (glass, metal, polymers) for different applications, like enhancement of tribological properties [30-32], thermal [33],corrosion protection [34,35] or adhesion promotion [36] to cite a few. Particularly, cell and proteinrepellent poly(ethylene glycol)-based hydrophilic surfaces were obtained through atmospheric pressure plasma spraying [37,38]. However, to the best of our knowledge, our team was the first to investigate hydrophobic atmospheric pressure plasma-sprayed coatings targeted at food-related fouling management [39].

This work therefore aims at studying the surface characteristics of siloxane-based coatings generated by solvent-free atmospheric pressure plasma spraying of liquid precursor HMDSO on food-grade stainless steel and at investigating their antifouling properties against isothermal dairy fouling. The coatings' behavior towards micro-organisms was also assessed through foodborne pathogenic bacterium adhesion tests. 


\section{EXPERIMENTAL METHODS}

\subsection{Substrates.}

$1 \mathrm{~mm}$-thick food-grade 316L stainless steel (SS) samples (Sapim Inox, France) were used as substrate throughout the study. $45 \mathrm{x} 15 \mathrm{~mm}^{2}$ samples were used for fouling assessment, and $10 \mathrm{x}$ $15 \mathrm{~mm}^{2}$ samples were used for imaging. Before being used, the steel surfaces were degreased in $50 / 50(\mathrm{v} / \mathrm{v})$ ethanol/acetone and washed in a $2 \%(\mathrm{v} / \mathrm{v})$ solution of RBS 35 commercial detergent at $65^{\circ} \mathrm{C}$. They were then rinsed with hot and room temperature deionized water and dried in air.

\subsection{Atmospheric Pressure Plasma Spraying (APPS) System.}

Plasma coatings were manufactured using an UL-Scan atmospheric pressure plasma spraying device (AcXys Technologies, France) associated with nebulizing system allowing to spray the precursor directly into the plasma plume, which results from an electric discharge in pure nitrogen. The chosen siloxane-containing liquid precursor was hexamethyldisiloxane (HMDSO) (Fluka). The plasma jet and the precursor nebulizer (Mira-Mist, AnalysenTechnik, Germany) were mounted on a 3-axis automaton (TableTop TT, IAI, Germany) allowing to scan the plasma spot over the substrate. This set-up (Figure 1) allows for several manufacturing parameters to vary and different deposition conditions were thus tested. The variable parameters were: the precursor flow rate $\mathrm{Q}(\mathrm{g} / \mathrm{h})$, the nozzle-to-substrate distance $\mathrm{D}(\mathrm{mm})$ and the scanning speed $\mathrm{v}$ $(\mathrm{mm} / \mathrm{s})$. All experiments were carried out at room temperature $\left(20^{\circ} \mathrm{C}\right)$. Nitrogen was used both as plasmagenic gas and precursor carrier gas, which flow rates were kept constant in all experiments, at 60 standard liter per minute (slm) and $1.9 \mathrm{slm}$, respectively. To enhance the coatings' adhesion on SS, an activation pretreatment, i.e. four passes of the plasma jet without any precursor spraying $\left(\mathrm{N}_{2}\right.$ flow rate $\left.=60 \mathrm{slm}, \mathrm{D}=20 \mathrm{~mm}, \mathrm{v}=100 \mathrm{~mm} / \mathrm{s}\right)$, was applied to all $\mathrm{SS}$ surfaces before coating. The efficiency of such pre-treatments has previously been demonstrated 
by Regula et al. (2009) and Szabová et al. (2009). The temperature of samples after exposure to plasma (T) was measured through K-type thermocouple. After activation, T reached $246^{\circ} \mathrm{C}$. The samples were left $15 \mathrm{~min}$ to cool down to room temperature $\left(20^{\circ} \mathrm{C}\right)$ before coating. The activated surfaces, i.e. exposed to plasma with no precursor spraying were then coated.

Table 1 summarizes all the tested deposition conditions. PL 1 can be considered as the "central" sample, with $\mathrm{Q}=35 \mathrm{~g} / \mathrm{h} ; \mathrm{D}=20 \mathrm{~mm}$ and $\mathrm{v}=100 \mathrm{~mm} / \mathrm{s}$. For PL 2 to 4 , HMDSO flow rate was modified. PL 5 and 6 present nozzle-to-substrate distance variations and finally, PL 7 and 8 present scanning speed variations.

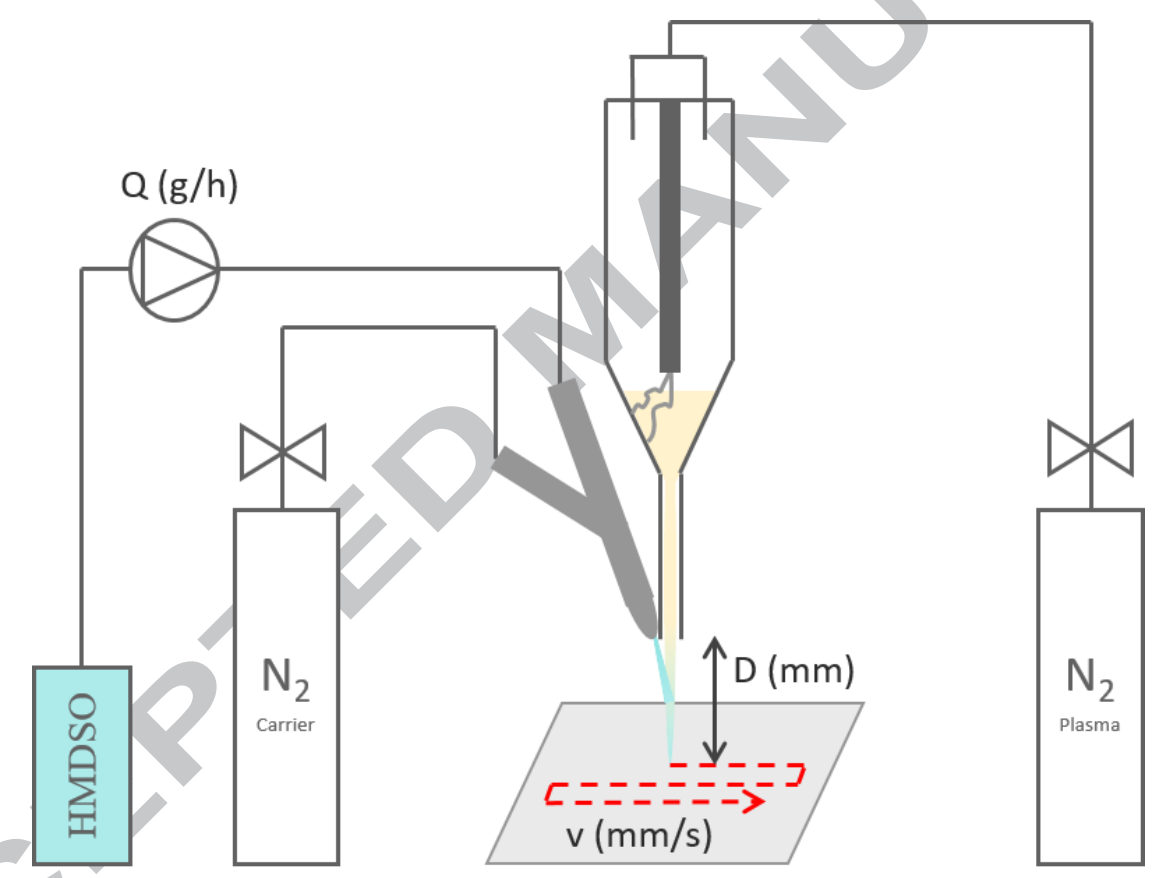

Figure 1: Schematic diagram of the UL-Scan device. 
Table 1: Deposition conditions for APPS coatings.

\begin{tabular}{lccccc}
\hline Precursor & Sample ID & $\begin{array}{c}\text { Precursor flow } \\
\text { rate } \\
\mathbf{Q}(\mathbf{g} / \mathbf{h})\end{array}$ & $\begin{array}{c}\text { Nozzle-to-sub. } \\
\text { distance } \\
\mathbf{D}(\mathbf{m m})\end{array}$ & $\begin{array}{c}\text { Scanning speed } \\
\mathbf{v}_{\mathbf{s}}(\mathbf{m m} / \mathbf{s})\end{array}$ & $\begin{array}{c}\text { Sample } \\
\text { Temperature } \\
\left({ }^{\circ} \mathbf{C}\right)\end{array}$ \\
\cline { 2 - 6 } & PL 1 & 35 & 20 & 100 & 113 \\
\multirow{5}{*}{ HMDSO } & PL 2 & 40 & 20 & 100 & 113 \\
& PL 3 & 30 & 20 & 100 & 133 \\
& PL 4 & 25 & 20 & 100 & 113 \\
& PL 5 & 35 & 10 & 100 & 132 \\
& PL 6 & 35 & 30 & 100 & 107 \\
& PL 7 & 35 & 20 & 50 & 124 \\
\hline
\end{tabular}

\subsection{Surface Characterizations}

\subsubsection{Goniometry}

The wettability of the different coatings were assessed with a DSA100 Goniometer (Krüss, Germany) through static water contact angle (WCA) measurements. $2 \mu \mathrm{L}$ water droplets were deposited on the substrate and the images were analyzed with the Advance 3.0 software.

Surface free energy (SFE) measurements were performed using the same device and software, following the Owens, Wendt, Rabel and Kaelble (OWRK) method (Equation 1 [41]) with deionized water, diiodomethane and formamide (Sigma-Aldrich) as probe fluids. This approach allows for total SFE $\left(\gamma^{\text {Total }}\right)$ to be decomposed between a polar $\left(\gamma^{\mathrm{P}}\right)$ and a dispersive $\left(\gamma^{\mathrm{D}}\right)$ component.

$\gamma_{S L}=\gamma_{S}+\gamma_{L}-2\left(\sqrt{\gamma_{S}^{D} \times \gamma_{L}^{D}} \times \sqrt{\gamma_{S}^{P} \times \gamma_{L}^{P}}\right)$

Equation 1

The resulting data are representative of at least 9 measurements ( 3 measurements on 3 droplets) for each probe fluid.

\subsubsection{Scanning Electron Microscopy (SEM)}

SEM pictures were obtained with a Hitachi S4700 device. A $5 \mathrm{kV}$ acceleration voltage and a current intensity of $15 \mu \mathrm{A}$ were implemented for all observations. 


\subsubsection{Electron-Probe Micro-Analyzer (EPMA)}

\section{$\underline{\text { Sample preparation }}$}

To obtain cross-section images, the samples were embedded in epoxy resin cylinders and then polished on a rotary polisher with abrasive silicon carbide paper (grades \#180 to \#2400) in order to get neat and smooth cross-sections.

When X-ray mappings of thin coatings are needed (below $1 \mu \mathrm{m}$ ), the sample is not embedded in epoxy resin, the cross section is directly polished by the mean of an ion polisher, Fischione 1060 SEM ion milling. A 5 hours polishing process was used, the argon beam was used at $4 \mathrm{kv}$ for 4hours for polishing and then at $1 \mathrm{kV}$ for 1 hour for cleaning.

\section{$\underline{\text { X-Ray Mappings }}$}

EPMA analyses were carried out with a Cameca SX100 electron probe micro-analyzer at $15 \mathrm{kV}$, 40 nA. X-ray mappings used PET crystal to detect the Ka of S (protein deposit) and Ca (mineral deposit), TAP crystal to detect the Ka of Si (plasma coating) and LiF crystal to detect the K $\alpha$ of Fe (steel substrate).

\subsubsection{Contact Profilometer}

Arithmetic mean roughness of the different samples was measured on an AlfaStep IQ surface profilometer (KLA-Tencor). The tip speed was $20 \mu \mathrm{m} / \mathrm{s}$ and profiles were recorded on $500 \mu \mathrm{m}-$ long segments. At least three measurements were carried out on each surface.

\subsubsection{Atomic Force Microscopy (AFM)}

The samples were imaged using a Dimension 3100 model AFM (Veeco) equipped with a Nanoscope IV controller (Digital Instruments) under ambient conditions. Single beam silicon cantilevers (AFM-TM Arrow, Nanoworld) with spring constants of $\sim 42 \mathrm{Nm}^{-1}$ and resonant frequencies of $\sim 250 \mathrm{kHz}$ were used. All AFM images were acquired in tapping mode and the image size was $200 \times 200 \mathrm{~nm}^{2}$. 


\subsubsection{Fourier-Transform Infrared Spectroscopy (FTIR)}

FTIR spectroscopy of the different coatings was performed on a Nicolet iS-50 spectrometer (Thermo Scientific), in the spectral range 500 to $4000 \mathrm{~cm}^{-1}$. Spectra post-treatment was done with Omnic 9 software.

\subsubsection{X-Ray photoelectron spectroscopy (XPS)}

XPS analysis were performed on a Kratos AXIS Ultra LDL device with a monochromatic Al K Al Ka X-ray source $(10 \mathrm{~mA}, 12 \mathrm{kV}) . \mathrm{C} 1 \mathrm{~s}, \mathrm{O}$ 1s, Fe 2p, Cr 2p, Ni 2p and Si $2 \mathrm{p}$ spectra were obtained using a $40 \mathrm{eV}$ pass energy. Spectra post-treatment was done using Casa XPS software (version 2.3.16, Casa Software Ltd.) All spectra were charge corrected to give the adventitious C1s component a binding energy of $284.8 \mathrm{eV}$.

\subsubsection{Cross-Hatch Adhesion Test}

The coating's adhesion on SS substrates was studied following the ASTM D3359-B standard with an Elcometer 107 cross-hatch cutter of $3 \mathrm{~mm}$ with 6 teeth. This procedure classifies coatings adhesion from 5B (very good adhesion) to $0 \mathrm{~B}$ (poor adhesion) ranges.

\subsection{Fouling Tests}

\subsubsection{Model Fluid}

A model fluid (MF) was used instead of fresh milk for fouling tests to ensure repeatability and control of the fouling process. Its formulation was chosen to approach skim milk $\beta$-lactoglobulin content [42]. This MF was a 1\% (w/v) solution of whey protein concentrate powder (Promilk 825 FB1, 80\% protein in dry state, IDI SAS, France) in reverse osmosis water. Proteins were left to rehydrate for 2 hours at room temperature, under stirring and then the calcium content was adjusted at $100 \mathrm{ppm}$ via $\mathrm{CaCl}_{2}$ adjunction in order to generate significant deposits during the run, 
while avoiding overpressure phenomena [6]. Five hundred liters of MF were freshly prepared for each fouling test. The $\mathrm{pH}$ value of this solution was 6.8 and the protein and calcium contents of each batch were checked via atomic absorption spectrometry and HPLC respectively.

\subsubsection{Pilot Pasteurizer}

The pilot pasteurizer used in this study (Figure 2) results from the downscale of an industrial process. It consists in a storage tank, a volumetric pump and two plate heat-exchangers (PHE) with V7 corrugated plates from Alfa-Laval Vicarb (France). The first PHE preheats the MF from room temperature to $65^{\circ} \mathrm{C}$. The second PHE heats the fluid to the pasteurization working temperature, i.e. $85^{\circ} \mathrm{C}$. The sample holder is connected just at the outlet of the heating section. The samples are therefore tested under isothermal conditions, like the inner surface of a holding section. Model fluid flow rate was $300 \mathrm{~L} / \mathrm{h}$, which corresponds to a Reynolds number of 2400 in the sample-holder (transient-turbulent regime). The plant was started with reverse osmosis water and switched to MF once steady-state regime was reached. A by-pass allowed to equilibrate the conditions with MF before circulating in the sample holders. To better mimic industrial conditions, the MF was not recirculated. Each fouling test lasted $1.5 \mathrm{~h}$, which is the threshold of fouling-induced pressure increase the system can withstand. After a first fouling test, the samples were rinsed for 20 min with hot water, taken out of the pasteurizer and left to dry completely in a cold room before to be weighted and analyzed. Some plasma coated samples were then submitted to a second fouling test, identical to the first one. In that second pasteurization run, clean bare SS surfaces were used as references. The fouling results presented in this article are representative of at least 3 replicates for each sample. 


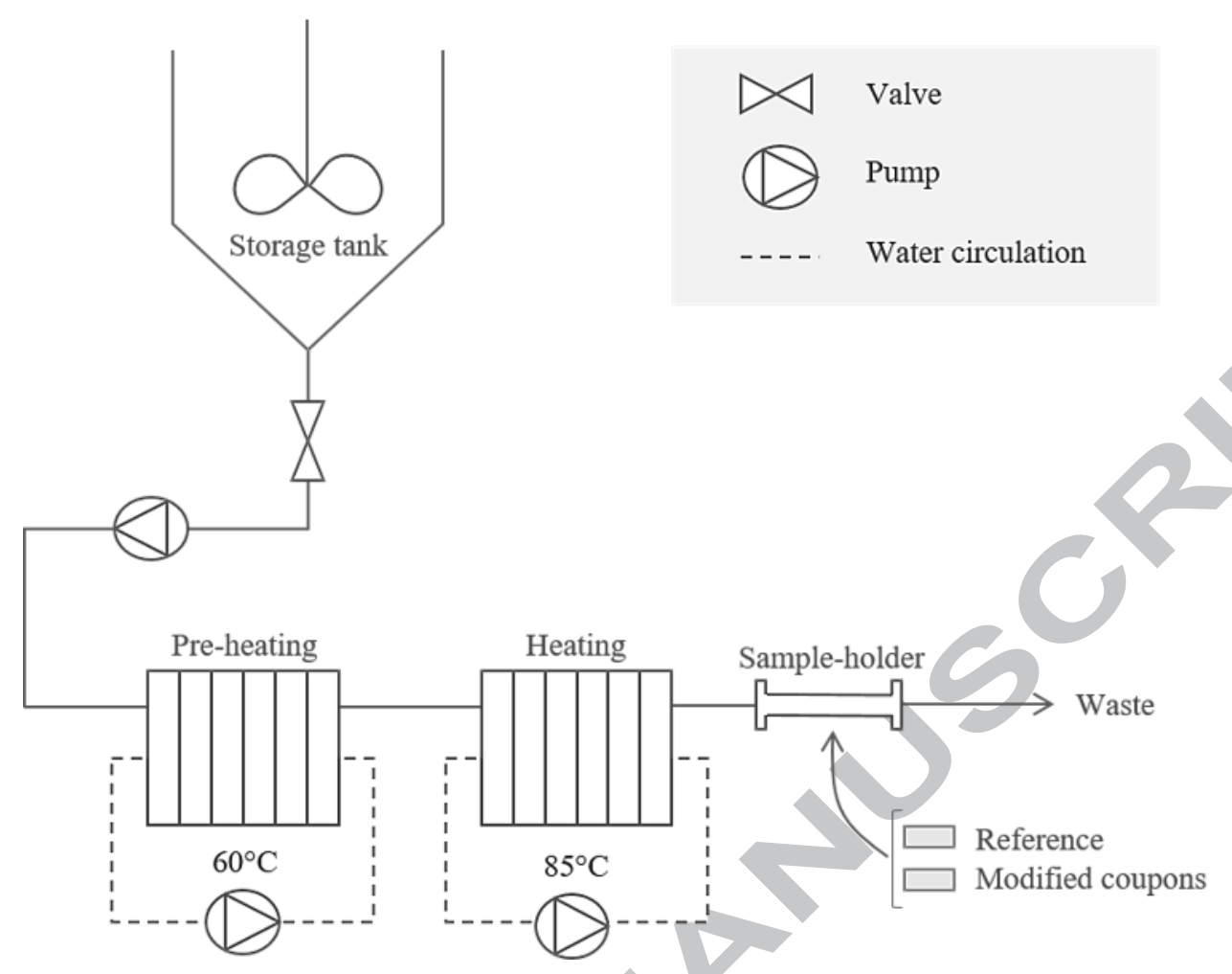

Figure 2: Pilot pasteurizer diagram [21].

\subsection{Bacterial Adhesion Assay}

Bacterial adhesion assays were carried out with Staphylococcus aureus CIP 4.83, a well-known foodborne pathogen bacterium. Pre-cultures were prepared by inoculating $100 \mu \mathrm{L}$ from frozen tubes into $5 \mathrm{ml}$ of Tryptic Soy Broth (TSB) and grown at $37^{\circ} \mathrm{C}$ for $24 \mathrm{~h}$. Main cultures were then prepared by inoculating $50 \mathrm{~mL}$ of TSB with $100 \mu \mathrm{L}$ from the pre-culture tubes and incubated at $37^{\circ} \mathrm{C}$ with shaking at $160 \mathrm{rpm}$. S. aureus cells were harvested at the late exponential phase of bacterial growth (centrifugation at $3000 \mathrm{rpm}, 4^{\circ} \mathrm{C}, 10 \mathrm{~min}$ ). The cells were then washed twice with $20 \mathrm{~mL}$ of physiological water (PW). After re-suspension in $\mathrm{PW}$ and sonication, the absorbance at $620 \mathrm{~nm}$ was checked by optical density measurements and the cell suspension was diluted to an estimated concentration of $10^{7} \mathrm{CFU} / \mathrm{mL}$. 
The different substrates were then covered with $3 \mathrm{~mL}$ of bacterial suspension. After one hour of static incubation, they were rinsed twice with PW and stained with acridine orange for 15 min. After two rinses with PW, the substrates were observed with an Olympus BX43 fluorescence microscope (x 100). The data presented in the paper are representative of 12 different samples for each surface ( 2 batches of 6 samples, tested on different days with different pre-cultures, 10 microscope fields per sample). 


\section{RESULTS AND DISCUSSIONS}

\subsection{Influence of the manufacturing parameters on surface properties.}

Wettability, surface energy and roughness features of the plasma coatings are gathered in Table

2.

Table 2: Surface properties of the HMDSO plasma coatings.

\begin{tabular}{|c|c|c|c|c|c|c|}
\hline \multirow{2}{*}{ Sample ID } & \multirow{2}{*}{$\begin{array}{c}\text { Water contact } \\
\text { angle } \\
\left({ }^{\circ}\right)\end{array}$} & \multicolumn{3}{|c|}{$\begin{array}{c}\text { Surface free energy } \\
(\mathrm{mN} / \mathrm{m})\end{array}$} & \multirow{2}{*}{$\begin{array}{l}\text { Arithmetic mean } \\
\text { roughness } \\
\operatorname{Ra}(\mathbf{n m})\end{array}$} & \multirow{2}{*}{$\begin{array}{c}\text { Adhesion } \\
\text { Grade }\end{array}$} \\
\hline & & $v^{\text {Total }}$ & $y^{D}$ & $\gamma^{P}$ & & \\
\hline Bare SS & $84.2 \pm 2.6$ & $41.9 \pm 4.3$ & $38.2 \pm 0.9$ & $3.7 \pm 2.5$ & $68 \pm 12$ & 7 \\
\hline Activated SS & $23.5 \pm 0.9$ & $64.7 \pm 15.0$ & $35.7 \pm 6.3$ & $29.0 \pm 9.1$ & $70 \pm 9$ & I \\
\hline PL 1 & $95.7 \pm 3.3$ & $37.7 \pm 1.8$ & $33.8 \pm 1.1$ & $3.92 \pm 0.7$ & $45 \pm 3$ & $5 \mathrm{~B}$ \\
\hline PL 2 & $79.3 \pm 4.0$ & $38.4 \pm 1.9$ & $35.7 \pm 1.0$ & $2.6 \pm 0.9$ & $51 \pm 1$ & $5 \mathrm{~B}$ \\
\hline PL 3 & $101.2 \pm 0.6$ & $44.0 \pm 3.7$ & $28.2 \pm 1.6$ & $15.8 \pm 2.0$ & $43 \pm 4$ & $5 \mathrm{~B}$ \\
\hline PL 4 & $101.5 \pm 1.0$ & $46.5 \pm 3.0$ & $32.0 \pm 1.1$ & $14.5 \pm 1.8$ & $41 \pm 3$ & $5 \mathrm{~B}$ \\
\hline PL 5 & $97.1 \pm 0.8$ & $43.3 \pm 4.0$ & $36.2 \pm 1.1$ & $7.1 \pm 2.9$ & $64 \pm 5$ & $5 \mathrm{~B}$ \\
\hline PL 6 & $94.3 \pm 2.2$ & $41.5 \pm 4.7$ & $34.3 \pm 2.3$ & $7.1 \pm 2.5$ & $49 \pm 3$ & $5 \mathrm{~B}$ \\
\hline PL 7 & $95.0 \pm 1.3$ & $48.5 \pm 7.0$ & $36.1 \pm 1.2$ & $12.7 \pm 5.8$ & $40 \pm 13$ & $5 \mathrm{~B}$ \\
\hline PL 8 & $95.4 \pm 1.4$ & $42.3 \pm 4.6$ & $32.0 \pm 1.3$ & $10.2 \pm 3.3$ & $51 \pm 4$ & $5 \mathrm{~B}$ \\
\hline
\end{tabular}

\subsubsection{Effect of the Activation Step}

Bare SS exhibits a static WCA value of $84.2 \pm 2.6^{\circ}$, which is slightly high compared to some existing papers [43], but is still consistent with other data found in the literature [44,45]. As expected, the plasma activation of SS significantly decreases the WCA of the substrates from $84.2 \pm 2.6^{\circ}$ to $23.5 \pm 0.9^{\circ}$ and consequently increases their SFE from $41.9 \pm 4.3 \mathrm{mN} / \mathrm{m}$ to $64.7 \pm$ $15.0 \mathrm{mN} / \mathrm{m}$. It is noticeable that, while the dispersive SFE components of bare and activated SS do not differ from each other $(38.2 \pm 0.9 \mathrm{mN} / \mathrm{m}$ vs $35.7 \pm 6.3 \mathrm{mN} / \mathrm{m}$, respectively), activation clearly has an effect on the polar component that shifted from $3.7 \pm 2.5 \mathrm{mN} / \mathrm{m}$ to $29.0 \pm 9.1$ $\mathrm{mN} / \mathrm{m}$. Plasma activation is indeed known to change surface chemistry and to generate reactive groups, like hydroxyls, on the treated substrates [34]. Activation has no impact on roughness, which was expected, as APPS does not deliver enough energy to melt and reshape stainless steel. 


\subsubsection{HMDSO Coatings}

Cross-hatch test revealed that all plasma coatings classify as 5B grade, which indicates that activation induced very good adhesion to the SS substrate. Similar effect of plasma activation was reported by Regula et al. (2009) [34], who showed better adhesion for HMDSO coatings on silver thanks to plasma-induced reductive species.

Overall, the HMDSO coatings exhibit mild to medium hydrophobicity with WCA between $79.3 \pm$ $4.0^{\circ}$ and $101.5 \pm 1.0^{\circ}$ and in all cases except PL 2 (which has been done with the highest HMDSO flow rate), the plasma coating increased surface hydrophobicity. Arithmetic mean roughness was decreased in presence of the coating, regardless of the deposition conditions. This was not surprising as the silicon-containing layer is expected to partly fill in some of the grain boundaries and structural defects of the SS surface. It is interesting to notice that while total SFE $\left(\gamma^{\text {Total }}\right)$ values of bare and coated SS, regardless of the coating conditions, do not present any significant difference, the polar component $\left(\gamma^{\mathrm{P}}\right)$ does evolve. PL 3, 4, 7 and 8 indeed exhibit higher $\gamma^{P}$ values than bare SS. In comparison, Rosmaninho et al. (2007) [17] reported very rough $(\mathrm{Ra}=206 \pm 48 \mathrm{~nm})$ and rather hydrophilic $\mathrm{SiO}_{\mathrm{x}}$ coatings obtained on SS with HMDSO through PECVD (plasma enhanced chemical vapor deposition, i.e. low pressure plasma), for which WCA vale was of $15 \pm 3^{\circ}, \gamma^{\text {Total }}$ was of $55.6 \pm 0.1 \mathrm{mN} / \mathrm{m}$ and $\gamma^{\mathrm{P}}$ was of $52.9 \pm 1.7 \mathrm{mN} / \mathrm{m}$. Beuf et al. (2003) [46] also studied PECVD $\mathrm{SiO}_{\mathrm{x}}$ coatings from HMDSO on stainless steel. Their coatings were less rough than that of Rosmaninho et al. (2007) and their SFE approached that of SS, as it is the case here. The differences observed between those coatings and the ones obtained here by APPS, although they originate from the same chemical precursor and similar processes, highlight the importance of manufacturing conditions on the final properties of a surface.

Characterization of the coatings' surfaces and comparisons between each other allowed to study the consequences of deposition parameters modification on the surface properties (Figure 3). 
Those comparisons pointed out that while the variation of HMDSO flow rate impacts the coating's properties, changes in nozzle-to-substrate distance and scan speed in the studied range do not: indeed, in those cases variations of WCA, SFE and Ra do not exceed the incertitude margins (Figure 3B and C).
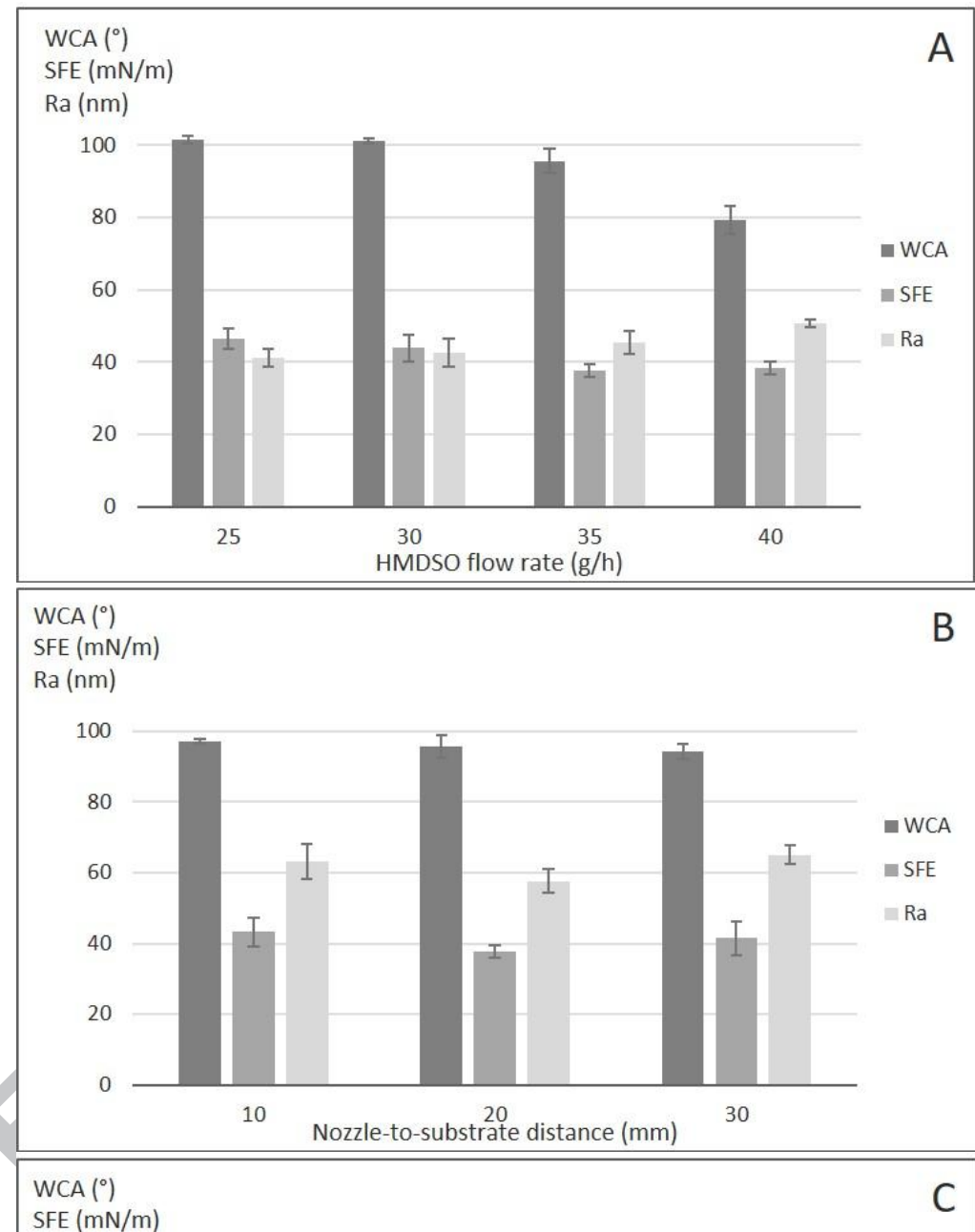

$\mathrm{Ra}(\mathrm{nm})$

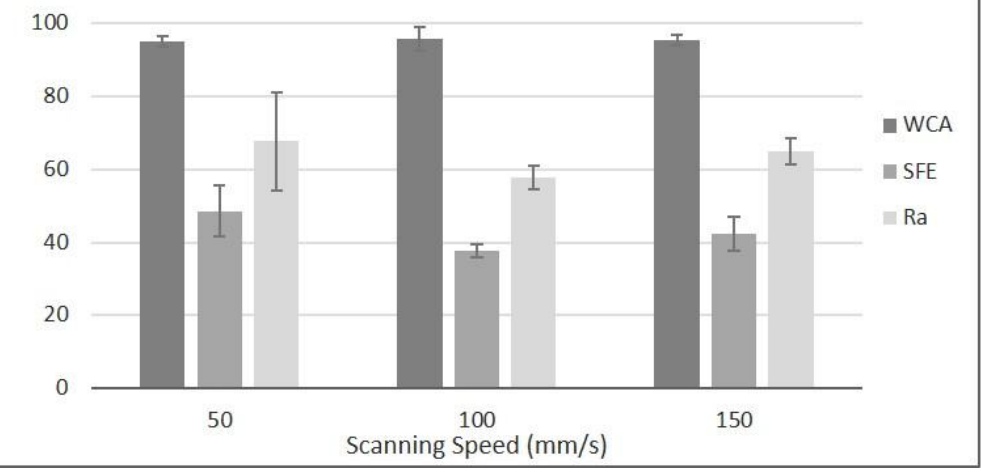


Figure 3: Surface characteristics of HMDSO coatings according to HMDSO flow rate (A), nozzle-to-substrate distance (B) and scanning speed (C).

Nevertheless, nozzle-to-substrate distance obviously impacts the residence time $\left(\mathrm{t}_{\mathrm{r}}\right)$ of the precursor in the plasma plume. This residence time can be assimilated to its travel time between the nozzle and the substrate, as HMDSO is nebulized right at the nozzle outlet. $t_{\mathrm{r}}$ value therefore correlates with the plasmagenic gas flow rate - as established by Lommatzsch \& Ihde (2009) which was kept constant at $601 / \mathrm{min}\left(10^{-3} \mathrm{~m}^{3} / \mathrm{s}\right)$ for all experiments. The speed of the gas can be approximated as the ratio between its flow rate and the nozzle section $\left(1.3 .10^{-5} \mathrm{~m}^{2}\right)$ to the value of $79.5 \mathrm{~m} / \mathrm{s}$. Consequently, for samples PL 1 to 4 and 7 to 8 , where D was kept constant at $20 \mathrm{~mm}$, HMDSO took $2.5 \cdot 10^{-4} \mathrm{~s}$ to reach the substrate surface, which is the $\mathrm{t}_{\mathrm{r}}$. For PL $5(\mathrm{D}=10 \mathrm{~mm})$ and PL $6(\mathrm{D}=30 \mathrm{~mm}), \mathrm{t}_{\mathrm{r}}$ was $1.5 \cdot 10^{-4} \mathrm{~s}$ and $3 \cdot 9 \cdot 10^{-4} \mathrm{~s}$, respectively. Considering that there is no significant difference between PL 1, 5 and 6 in terms of WCA, SFE or roughness (Figure 3A), it could then be concluded that in the present conditions, the precursor reaches its final degradation state within $1.5 .10^{-4} \mathrm{~s}$ after penetration in the plasma plume.

On the other hand, the increase of HMDSO flow rate clearly impacts the coatings' WCA and roughness. Nevertheless, the corresponding SFE values do not differ significantly from one another (Figure 3C). This can seem surprising, as SFE and WCA are generally considered to vary together (WCA increases as SFE decreases). Nevertheless, as roughness also fluctuates, the WCA decrease is susceptible to be the consequence of morphological differences between the samples rather than chemical ones. It is indeed known that surface roughness impacts the apparent water contact angle of a surface as stated by the Wenzel's equation (Equation 1 [48]) which links this apparent contact angle $\left(\theta_{\mathrm{w}}{ }^{*}\right)$ to the real "flat" one $(\theta)$, i.e. the contact angle resulting only from surface chemistry.

$\cos \theta^{*}{ }_{w}=r \cos \theta$

Equation 1 
In the present case, SEM micrographs of coatings (Figure 4) generated with three different HMDSO flow rates (25, 35 and $40 \mathrm{~g} / \mathrm{h}$ respectively) reveal an evolution of the surface morphology vs flow rate increase. At $25 \mathrm{~g} / \mathrm{h}$, the surface of the coating looks smooth, but when $\mathrm{Q}_{\text {HMDSO }}$ rises to $35 \mathrm{~g} / \mathrm{h}$, scattered lumps appear. The coating generated with the highest flow rate (40 g/h) has a very grainy, lumpy look which corroborates the existing literature stating that higher precursor flow rate induces the formation of powder in the plasma plume and the integration of particles in the coatings [47]. Moreover, FTIR spectra of coated stainless steel with $25 \mathrm{~g} / \mathrm{h}$ and $40 \mathrm{~g} / \mathrm{h}$ of HMDSO (Figure 5) prove that HMDSO flow rate had no significant effect on the coatings' chemistry, which is in accordance with the findings of Lommatzsch and Ihde (2009) [47]. Consequently, it can be suggested that the WCA changes come from morphological variations.

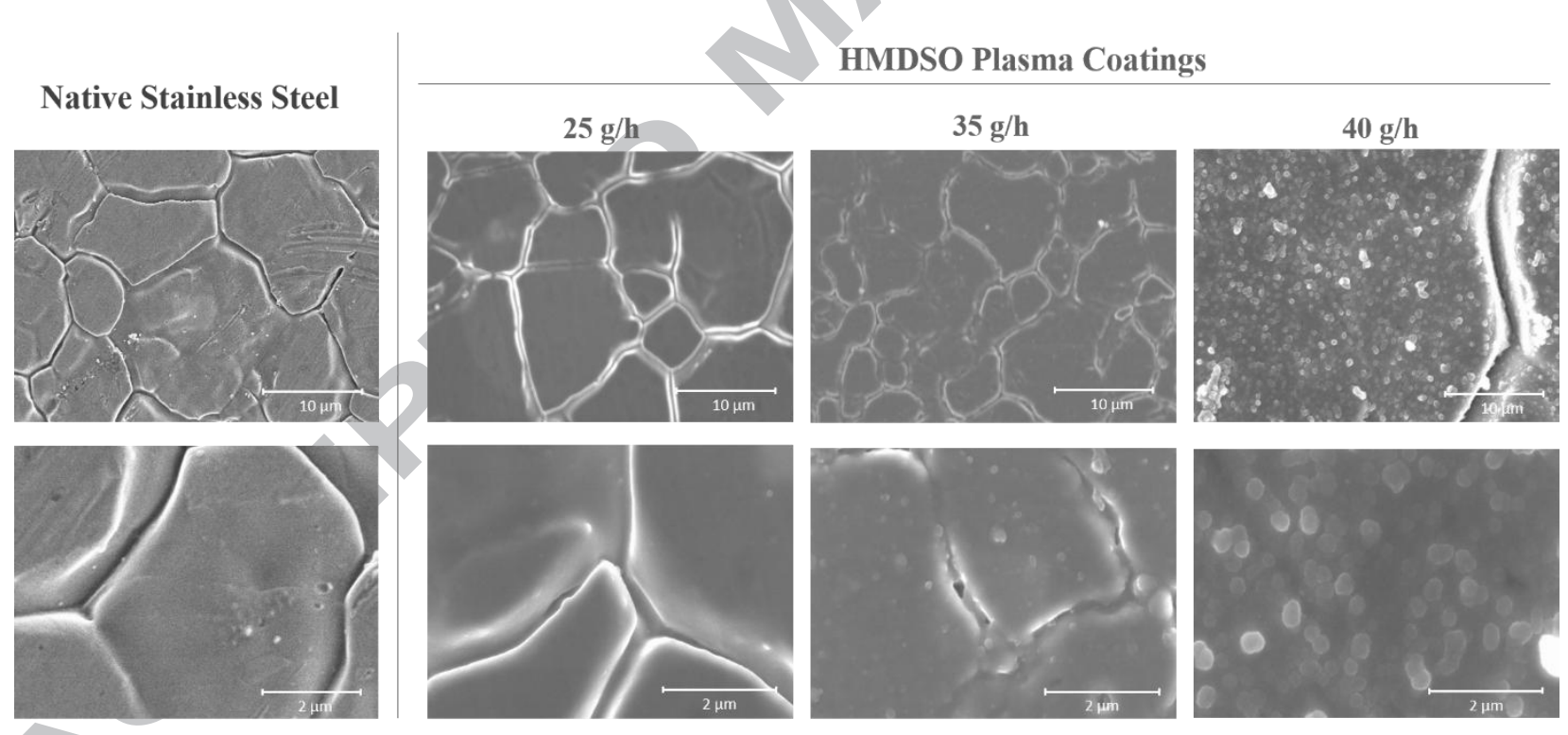

Figure 4: SEM surface micrographs of different HMDSO coatings compared to native stainless steel. 


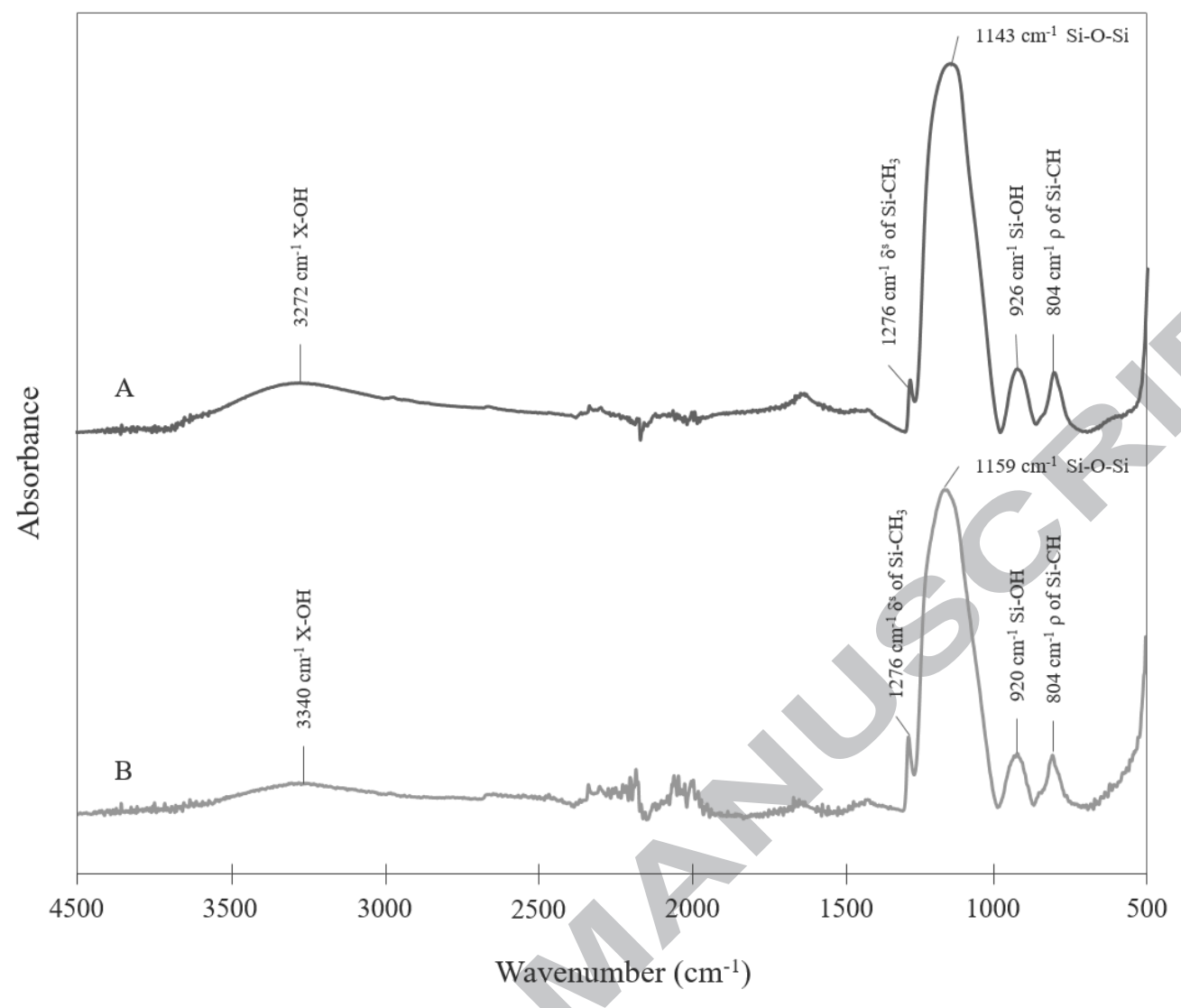

Figure 5: FTIR spectra of HMDOS APPS coatings with two different precursor flows, $25 \mathrm{~g} / \mathrm{h}$ (A) and $40 \mathrm{~g} / \mathrm{h}(\mathrm{B})$.

\subsection{Fouling results}

All samples were submitted to two consecutive fouling runs, to study their antifouling performances and to perform a first quantitative evaluation of their durability. Native stainless steel was taken as reference in all experiments. Samples were weighted before and after each fouling test and their fouling percentages $(\mathrm{F} \%)$ were calculated according to Equation 2.

$$
F \%=\frac{\left(M_{P L i}-M_{R e f}\right)}{M_{R e f}} \times 100
$$

F\%: $\quad$ Percentage of fouling gained or lost compared to the reference (-)

$M_{P L}$ i: $\quad$ Deposit mass on sample PL i (mg)

$M_{\text {Ref: }} \quad$ Deposit mass on the reference bare stainless steel ( $\mathrm{mg}$ ) 
After their first use, all HMDSO coatings presented very good antifouling behaviors regardless of the deposition conditions (Figure 6), with F\% comprised between -90 wt. \% and -99 wt. \%. The present hydrophobic plasma coatings were nevertheless able to reduce significantly dairy fouling in a simulated pasteurization holder. In comparison, Beuf et al. (2003) [46] and Rosmaninho et al. (2007) [17] reported that plasma enhanced chemical vapor deposition (PECVD), i.e. vacuum plasma $\mathrm{SiO}_{\mathrm{x}}$ coatings had mediocre to disadvantageous effect on dairy fouling. However, the coatings reported in those two studies were rather hydrophilic and rough, which are two foulingpromoting factors [49]. Moreover, the present atmospheric plasma coating SFE do not differ from the one of bare SS, and the polar components $\gamma^{\mathrm{P}}$ are generally higher than the one of stainless steel (Table 2). Such sets of surface free energy parameters are usually considered as unfavorable for fouling reduction [17]. The antifouling action of plasma coating is thus very likely to lie with the generally acknowledged chemical inertness of siloxanes.

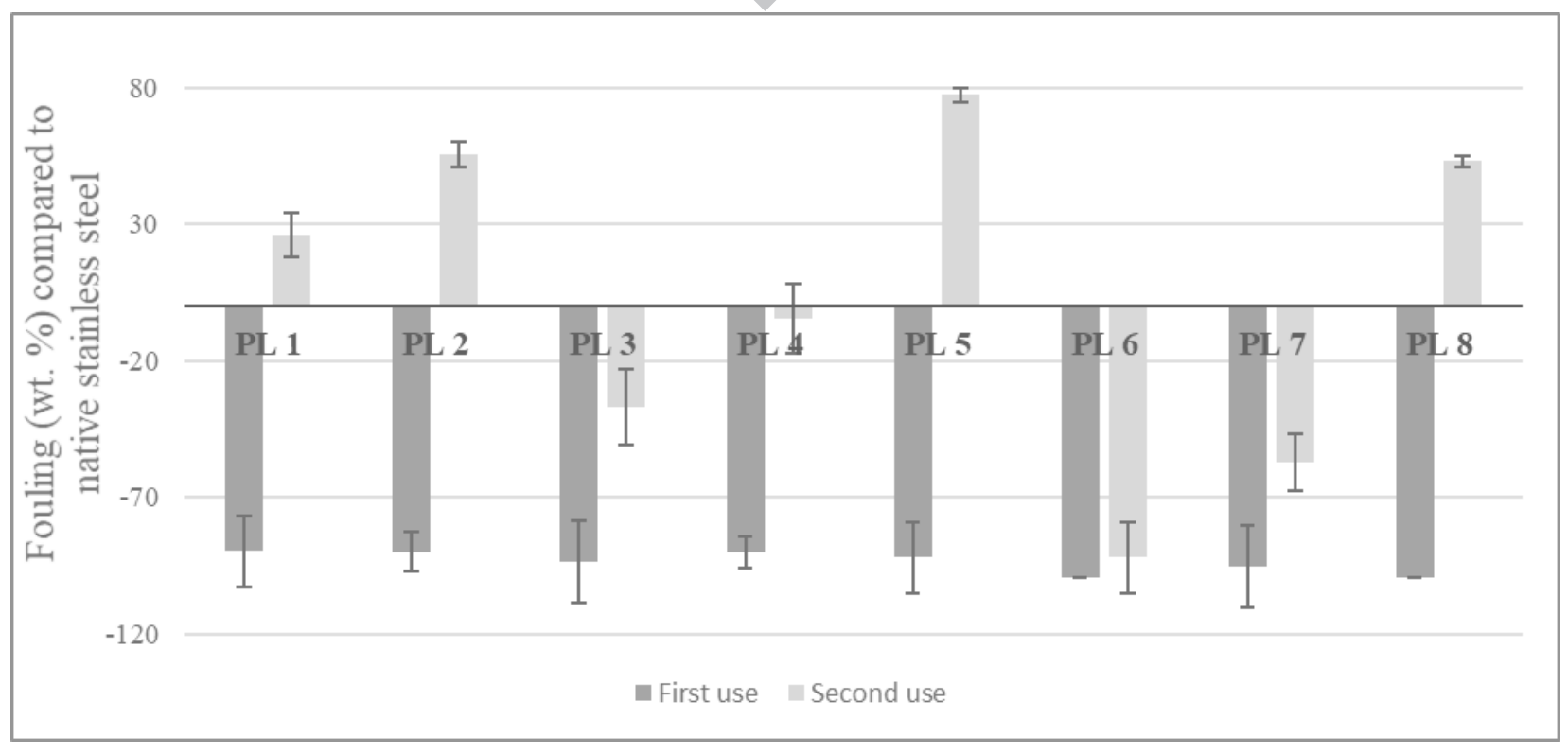

Figure 6: Fouling performances of HMDSO APPS coatings.

However, after the second fouling test, coatings exhibit very variable F\%. Particularly, PL 1, 2, 5 and 8 present a fouling increase compared to bare SS whereas PL 3, 4 and 7 exhibit clear loss of 
nonfouling properties. On the other hand, PL $6(35 \mathrm{~g} / \mathrm{h} ; 30 \mathrm{~mm} ; 100 \mathrm{~mm} / \mathrm{s})$ remained close to its original fouling performance. One possible explanation is that, depending on surface morphology, some deposit from the first use persisted more or less on the coatings and acted as a promoting basis for further deposition during the second testing run. Indeed, WCA measures carried on coatings after their first use showed a clear shift for all coatings towards hydrophilicity, except for PL6, whose post-fouling WCA stayed close to its initial value (Table 3). Dairy fouling deposits are composed of hydrophilic protein and minerals, and the observed decrease of WCA is consistent with residual deposits on the substrates. By comparison, control measurements carried out on coatings that were immersed in $85^{\circ} \mathrm{C}$ water for $1.5 \mathrm{~h}$ showed WCA values very close to that of pristine coatings.

Table 3: Water contact angle of the coatings in pristine state, after the first fouling test and after a $1.5 \mathrm{~h}$ immersion in hot water.

\begin{tabular}{cccc}
\hline Sample ID & $\begin{array}{c}\text { Pristine WCA } \\
\left({ }^{\circ}\right.\end{array}$ & $\begin{array}{c}\text { WCA after 1 }^{\text {st }} \\
\text { fouling test }\end{array}$ & $\begin{array}{c}\text { WCA after a1.5 h } \\
\text { immersion in hot } \\
\text { water }\end{array}$ \\
\hline PL 1 & $95.7 \pm 3.3$ & $68.4 \pm 2.2$ & $95.2 .5 \pm 2.5$ \\
PL 2 & $79.3 \pm 4.0$ & $57.0 \pm 2.7$ & $76.6 \pm 1.7$ \\
PL 3 & $101.2 \pm 0.6$ & $61.8 \pm 4.0$ & $101.1 \pm 1.4$ \\
PL 4 & $101.5 \pm 1.0$ & $61.7 \pm 4.0$ & $102.4 \pm 0.9$ \\
PL 5 & $97.1 \pm 0.8$ & $63.0 \pm 1.4$ & $97.7 \pm 1.5$ \\
PL 6 & $94.3 \pm 2.2$ & $93.2 \pm 1.1$ & $93.8 \pm 2.4$ \\
PL 7 & $95.0 \pm 1.3$ & $78.9 \pm 0.8$ & $96.1 \pm 1.7$ \\
PL 8 & $95.4 \pm 1.4$ & $63.1 \pm 2.7$ & $94.8 \pm 3.8$ \\
\hline
\end{tabular}

From this point, the focus will be taken on PL6, in order to elucidate the reasons for its good performances.

Figure 7 presents cross-section EPMA X-Ray Mappings performed on PL 6 coating after two consecutive fouling tests compared to bare SS. The arborescent look of dairy fouling on native stainless steel (Figure 7B) and the presence of calcium in forms of particles (Figure 7C) are consistent with previous observations of isothermal fouling [5,21]. 
The HMDSO coating is apparent (Figure 7G) and its thickness can be approximated to $150 \mathrm{~nm}$. As a matter of fact, coating thickness did not vary according to manufacturing conditions, probably because the studied flow rate variation range is too small to have a significant impact. The difference between dairy fouling on bare steel and on PL 6 coating is striking. The deposit forms a continuous $250-300 \mu \mathrm{m}$-thick film on the reference after one fouling test, whereas only $5 \mu \mathrm{m}$-thick isolates are found on PL 6 after two pasteurization cycles.

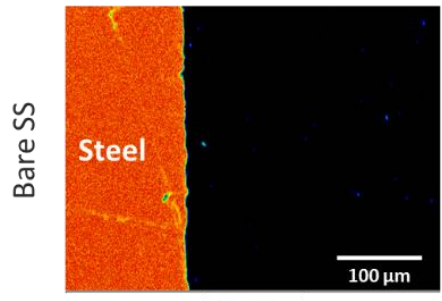

$\mathrm{Fe} \mathrm{K} \alpha$

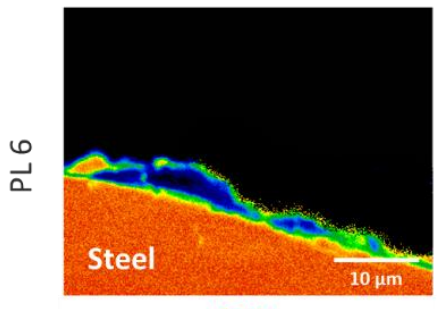

$\mathrm{Fe} \mathrm{K} \alpha$

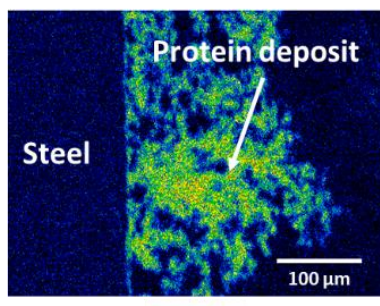

$\mathrm{SK} \alpha$

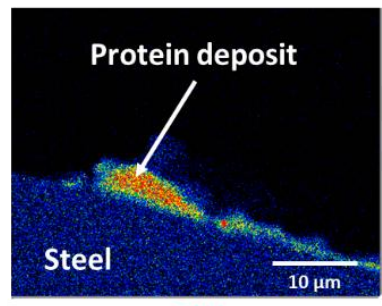

$\mathrm{S} \mathrm{K \alpha}$

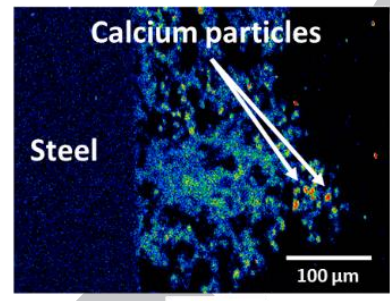

$\mathrm{Ca} \mathrm{K} \alpha$

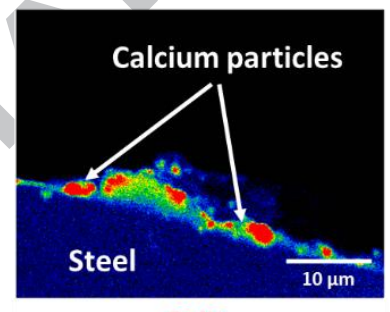

$\mathrm{Ca} \mathrm{K} \alpha$

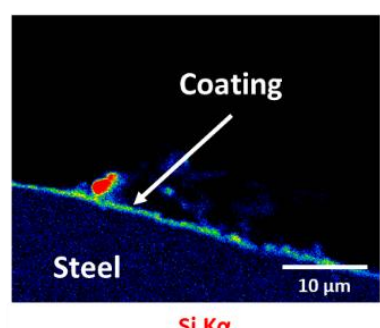

Si Ka

Figure 7: Cross-section EPMA X-ray Mappings of one-time fouled bare stainless steel (top row) and two-time fouled PL 6 coating (bottom row).

XPS analyses (Figure 8) indeed showed the presence of oxygen, carbon and silicon at the surface of PL 6 coatings, whereas iron, nickel, oxygen and carbon were found on bare SS. Component analysis of the different elements on both surfaces allowed to investigate closely their composition. On bare $\mathrm{SS}$, the study of $\mathrm{Fe} 2 \mathrm{p}$ and $\mathrm{Cr} 2 \mathrm{p}$ spectra (Figure 9) following the decomposition proposed by [50] revealed the strong presence of iron and chromium oxides, which are electron donor components, very prone to bound unfolded whey protein [51]. On PL 6, the Si $2 p$ binding energy (102.8 eV) was found to match exclusively that of siloxane [52] and the O 1 s binding energy $(532.6 \mathrm{eV})$ to match exclusively that of the oxygen atom of a $\mathrm{Si}-\mathrm{O}-\mathrm{Si}$ group 
(Figure 10) [53]. The PL 6 coating's surface is thus rich in Si-O-Si groups, which are electron acceptors [54]. The antifouling properties of PL 6 coatings are thus consistent with the findings of Boxler et al. (2013a), who established the antifouling properties of Si-O doped coatings against dairy proteins.
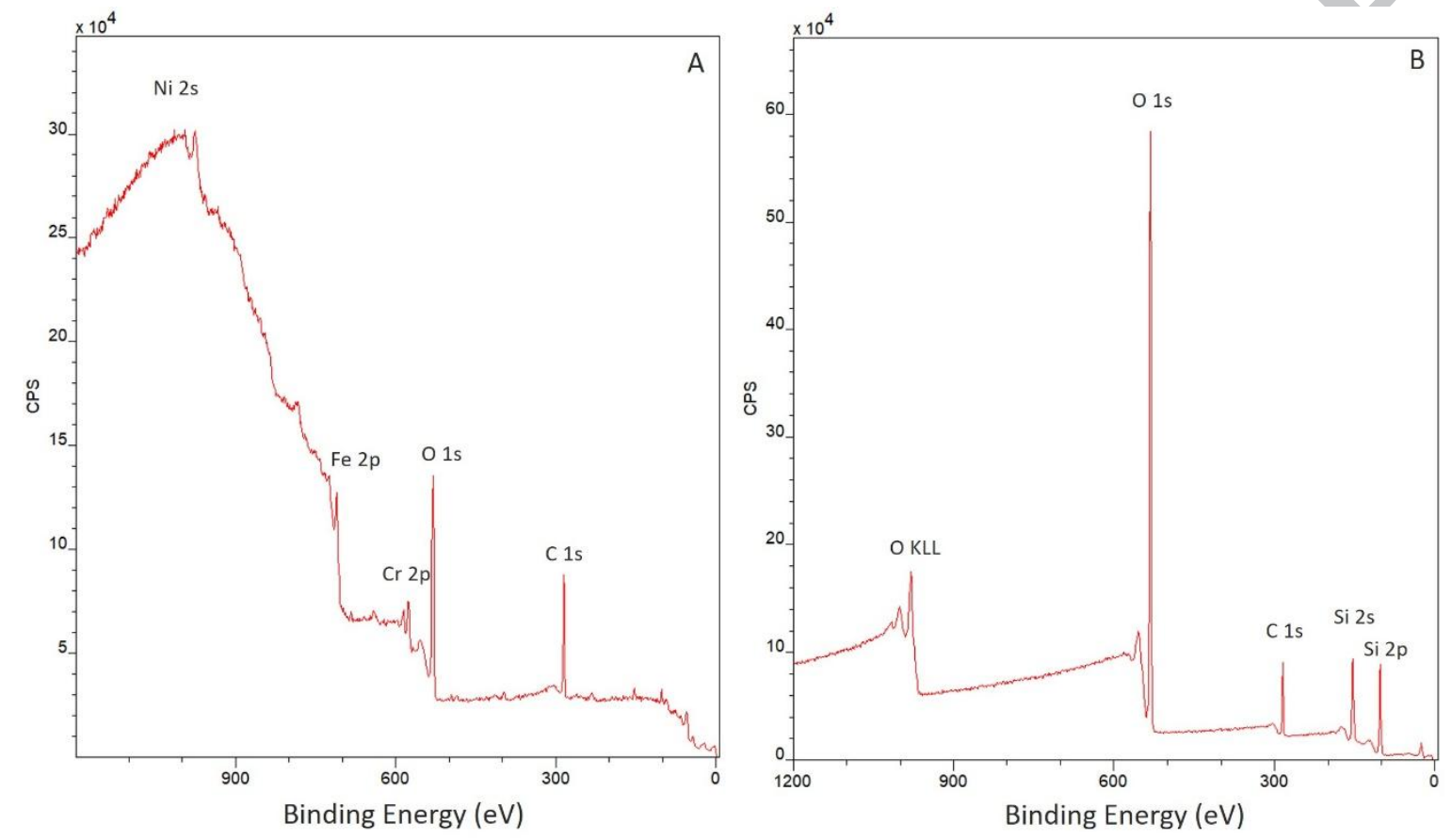

Figure 8: XPS surveys of bare stainless steel (A) and PL 6 coating (B).
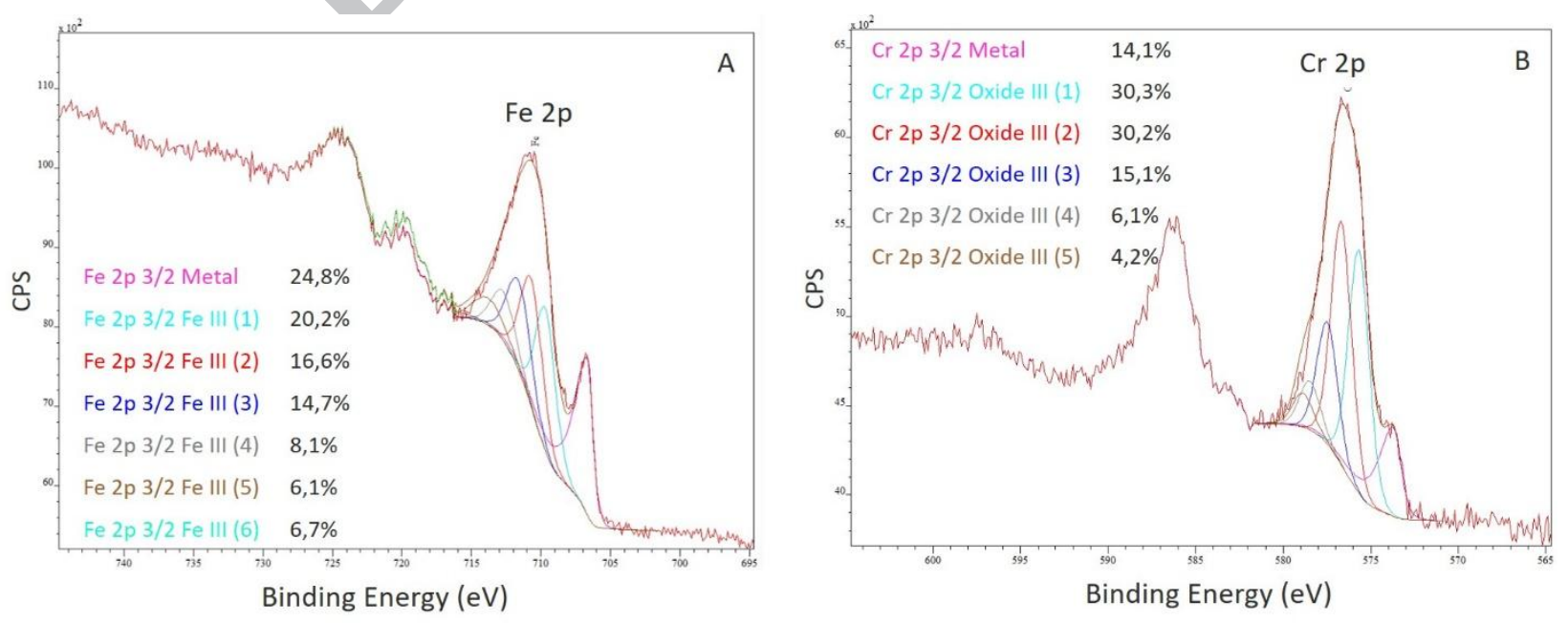

Figure 9: XPS Spectra of Fe (A) and Cr (B) in bare stainless steel. 

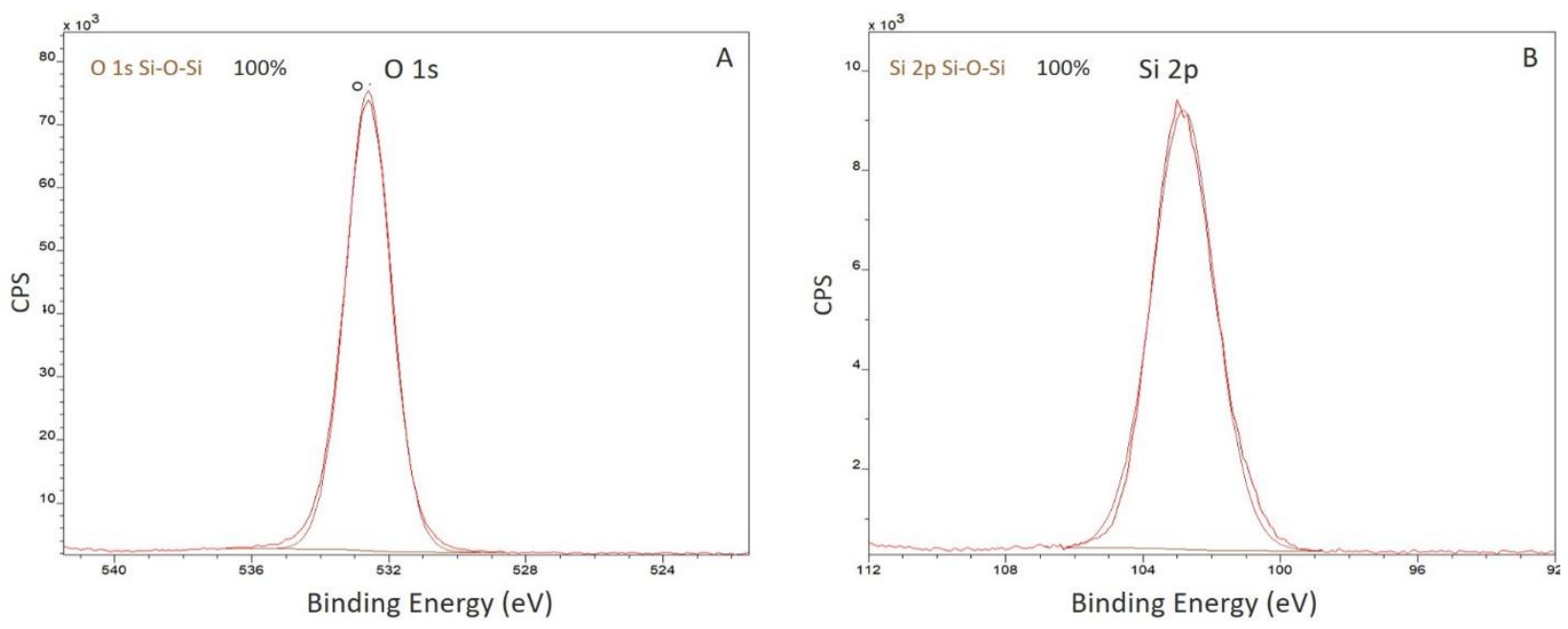

Figure 10: XPS Spectra of O (A) and Si (B) in PL 6 coating.

AFM observations of bare SS and PL 6 (Figure 11) revealed a drastic change in surface morphology induced by plasma coating, although the plasma coating is too thin to fill completely the grain boundaries of the stainless steel substrate. Indeed, while bare SS presents hundrednanometer deep and wide defects, nano-peaks are visible on PL 6. This nano-roughness is reminiscent of nanotextured and antiadhesive biological surfaces (e.g. lotus leaves). In the case of PL 6, this particular morphology, allied to the chemical features mentioned earlier, certainly lowered deposit adhesion and prevented interlocking of dairy foulant particles whose diameters are of 50-60 nm. Previous work indeed pointed out the importance of the relative size of surface relief versus foulants, suggesting that nano-roughness could be beneficial regarding fouling management $[5,21]$. 

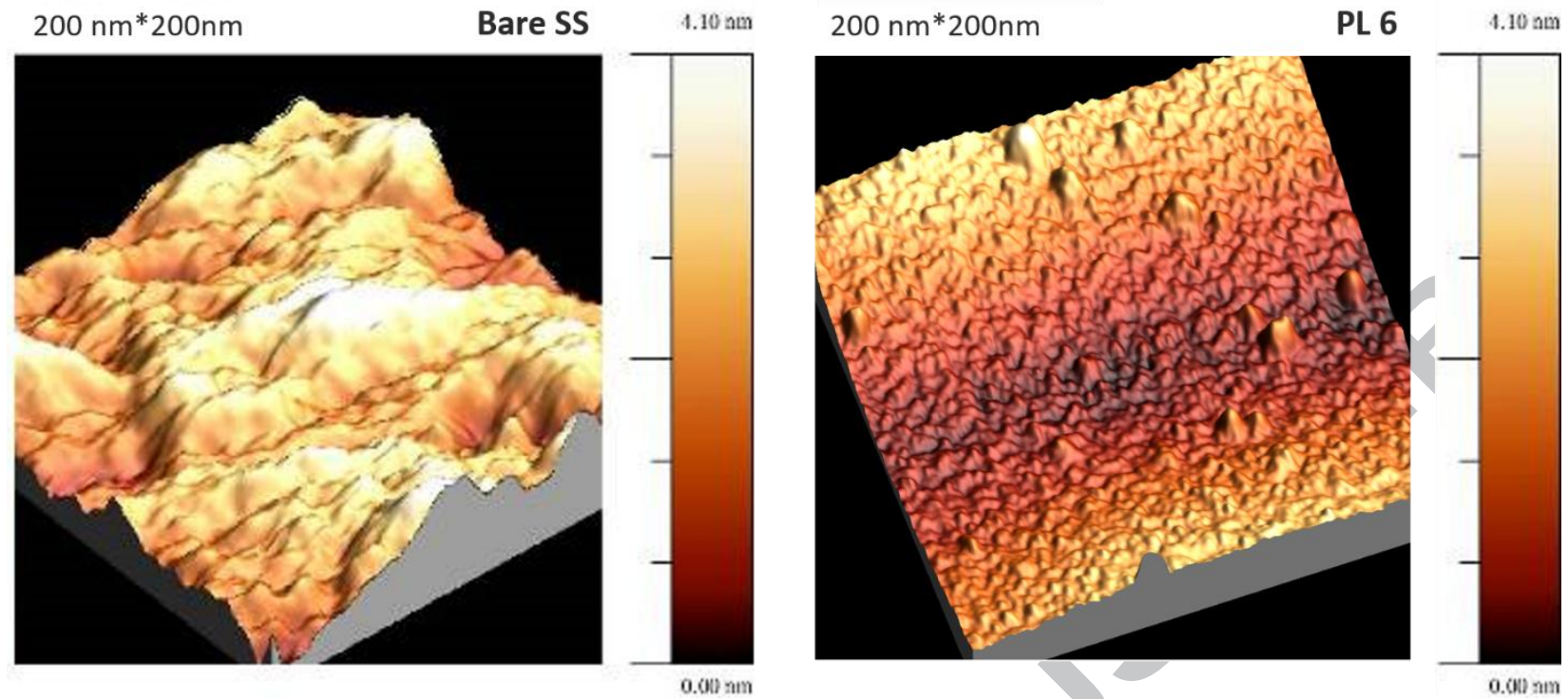

Figure 11: AFM pictures of bare SS and PL 6 coating.

\subsection{Bacterial Adhesion.}

The observation and comparison of bare stainless steel and PL6 coating (Figure 12) revealed that plasma treatment had a significant impact on S. aureus adhesion. It was indeed observed that the adhesion rate of bacterial cells are reduced by $30 \%$ on PL6 surfaces when compared to native surface: bare stainless steel presented an adhesion rate of $48 \pm 6$ cells per microscopic field, whereas PL6 samples showed an adhesion rate of $34 \pm 7$ cells per microscopic field. Microscopic observations moreover evidenced that a significant part of adhered cells on PL6 were located in the surface's grain boundaries (Figure 13). This impact of surface topography on bacterial adhesion has been previously reported [56,57]. A polishing step before plasma treatment should thus improve the coating's resistance to bacterial adhesion. 


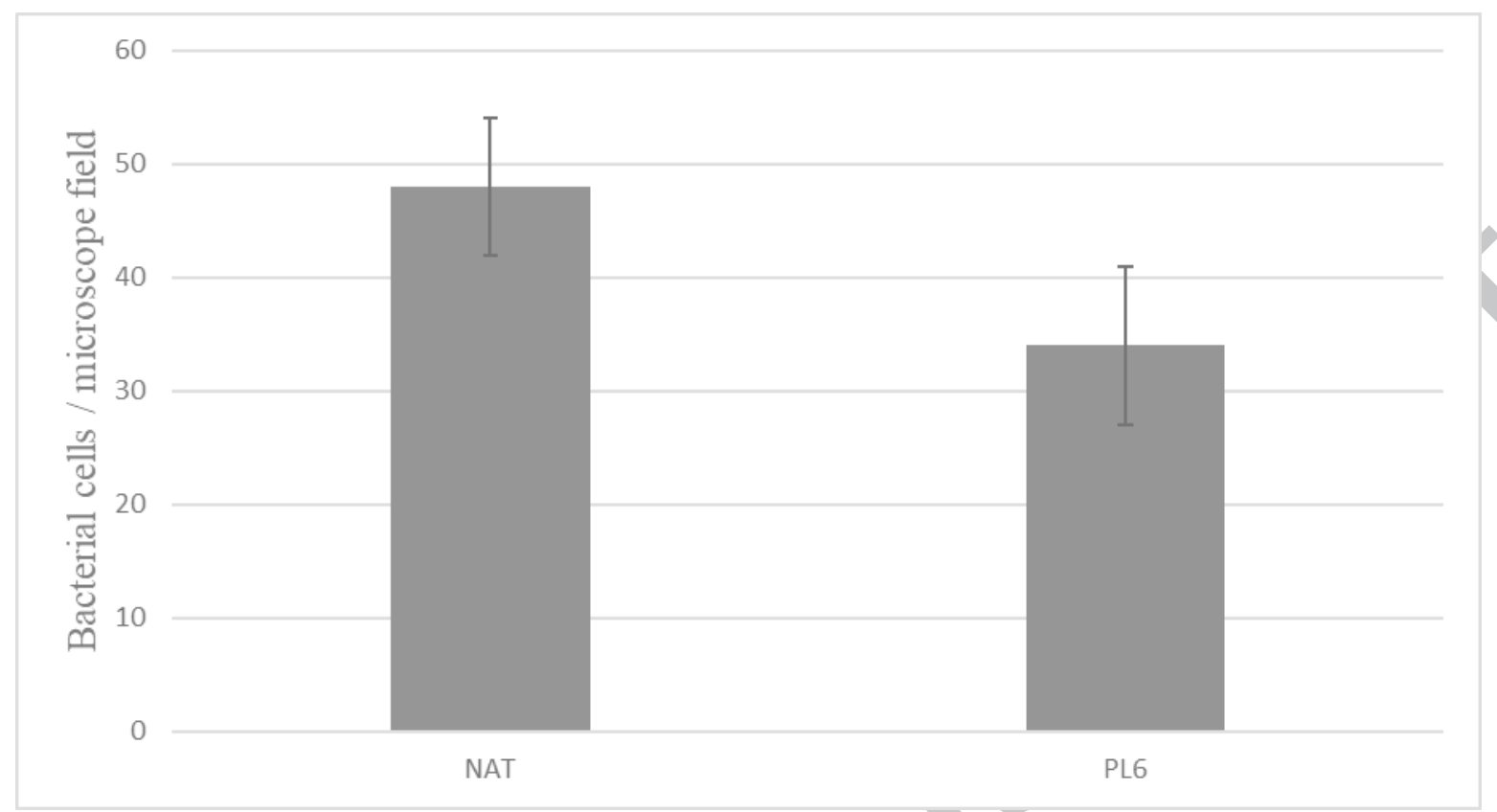

Figure 12: Staphylococcus aureus total cell counts on native stainless steel and PL6 coating after 1 hour of static adhesion test.

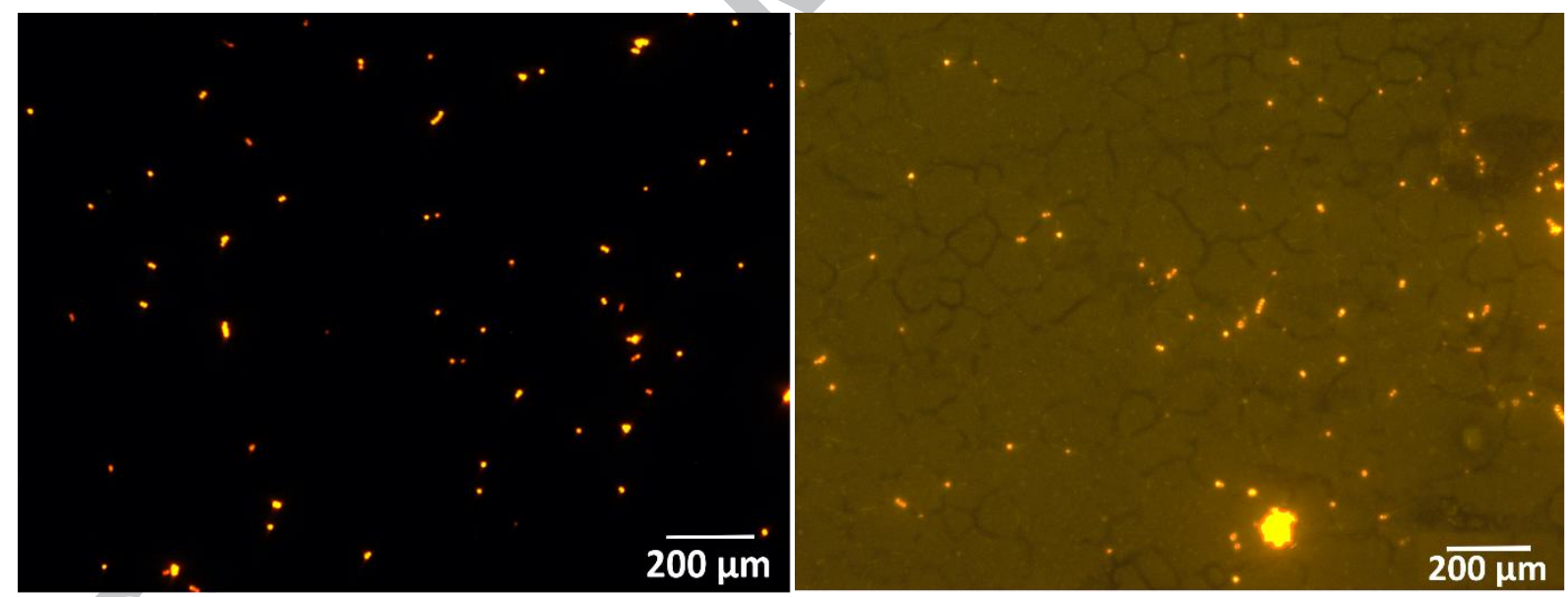

Figure 13: Fluorescence microscopy picture of bare SS (left) and PL6 surface (right) after $1 \mathrm{~h}$ of S. aureus adhesion. 


\section{CONCLUSIONS}

Atmospheric pressure plasma spraying was successfully used to generate thin, very adhesive, hydrophobic silane-based coatings on food-grade stainless steel. The impact of manufacturing conditions (precursor flow rate, scanning speed and nozzle to substrate distance) on the coatings' surface properties was investigated. Variation of precursor flow was shown to significantly impact surface roughness and morphology of the coatings, as particles are formed in the plasma plume when precursor flow increases. Those particles, included in the film, generate uneven morphologies. However, no significant effect of scanning speed or distance between the nozzle and the substrate was witnessed in the chosen variation ranges. Further research should definitely study the impact of other ranges for manufacturing conditions.

HMDSO coated samples were tested against dairy fouling under industrial conditions. They were shown to be efficient antifouling surfaces, however, as expected, the manufacturing conditions impacted the coatings' performances. The best performing coating, which allowed to reduce dairy fouling by more than $90 \%$ for two consecutive fouling runs, was closely characterized. Its nanostructured Si-O-Si rich surface was demonstrated to be well fitted for fouling reduction. This plasma treatment also proved to reduce by $30 \%$ the number of $S$. aureus adherent cells compared to native stainless steel.

Further research will be dedicated to the optimization of the manufacturing parameters through experimental design in order to produce coatings with tuned surface properties targeting antifouling in isothermal or non-isothermal conditions. Surface roughness of the treated stainless steel should also be investigated. 


\section{SUPPLEMENTARY DATA}

The supplementary data include the quantitative fouling performances of the different plasma coatings.

\section{ACKNOWLEDGEMENTS}

The authors would like to thank the Région Hauts-de-France and University of Lille-Sciences and Technologies (France) for funding this project. They also thank the french Agence Nationale de la Recherche (ANR) through the ECONOMICS project (ANR-17-CE08-0032) for its financial support and the Common Microscopy Center of UMET for the SEM and EPMA analysis. Chevreul Institute (FR 2638), Ministère de l'Enseignement Supérieur et de la Recherche and FEDER are also acknowledged for supporting and funding this work. 


\section{REFERENCES}

[1] A.J. Van Asselt, M.M.M. Vissers, F. Smit, P. De Jong, In-Line control of fouling, Proc. Heat Exch. Fouling Clean. (2005).

[2] L.G. da Cruz, E.M. Ishiyama, C. Boxler, W. Augustin, S. Scholl, D.I. Wilson, Value pricing of surface coatings for mitigating heat exchanger fouling, Food Bioprod. Process. 93 (2015) 343-363.

[3] T. Mérian, J.M. Goddard, Advances in Nonfouling Materials: Perspectives for the Food Industry, J. Agric. Food Chem. 60 (2012) 2657-2943.

[4] J. Visser, T.J.M. Jeurnink, Fouling of Heat Exchangers in the Dairy Industry, Exp. Therm. Fluid Sci. 14 (1997) 407-424. doi:http://dx.doi.org/10.1016/S0894-1777(96)00142-2.

[5] M. Jimenez, G. Delaplace, N. Nuns, S. Bellayer, D. Deresmes, G. Ronse, G. Alogaili, M. Collinet-Fressancourt, M. Traisnel, Toward the Understanding of the Interfacial Dairy Fouling Deposition and Growth Mechanisms at a Stainless Steel Surface: A Multiscale Approach, J. Colloid Interface Sci. $404 \quad$ (2013) 192-200. doi:http://dx.doi.org/10.1016/j.jcis.2013.04.021.

[6] J. Petit, T. Six, A. Moreau, G. Ronse, G. Delaplace, Beta-Lactoglobulin Denaturation, Aggregation, and Fouling in a Plate Heat Exchanger: Pilot-scale Experiments and Dimensional Analysis, Chem. $\quad$ Eng. Sci. $101 \quad$ (2013) 432-450. doi:http://dx.doi.org/10.1016/j.ces.2013.06.045.

[7] W. Yang, D. Li, X.D. Chen, R. Mercadé-Prieto, Effect of calcium on the fouling of whey protein isolate on stainless steel using QCM-D, Chem. Eng. Sci. 177 (2018) 501-508. doi:https://doi.org/10.1016/j.ces.2017.12.004.

[8] P. Blanpain-Avet, A. Hédoux, Y. Guinet, L. Paccou, J. Petit, T. Six, G. Delaplace, 
Analysis by Raman Spectroscopy of the Conformational Structure of Whey Proteins Constituting Fouling Deposits During the Processing in a Heat Exchanger, J. Food Eng. 110 (2012) 86-94. doi:http://dx.doi.org/10.1016/j.jfoodeng.2011.12.005.

[9] M. Khaldi, G. Ronse, C. André, P. Blanpain-Avet, L. Bouvier, T. Six, S. Bornaz, T. Croguennec, R. Jeantet, G. Delaplace, Denaturation Kinetics of Whey Protein Isolate Solutions and Fouling Mass Distribution in a Plate Heat Exchanger, Int. J. Chem. Eng. 2015 (2015).

[10] P. Blanpain-Avet, C. André, M. Khaldi, L. Bouvier, J. Petit, T. Six, R. Jeantet, T. Croguennec, G. Delaplace, Predicting the Distribution of Whey Protein Fouling in a Plate Heat Exchanger Using the Kinetic Parameters of the Thermal Denaturation Reaction of $\beta$ lactoglobulin and the Bulk Temperature Profiles, J. Dairy Sci. 99 (2016) 9611-9630. doi:https://doi.org/10.3168/jds.2016-10957.

[11] M.T. Belmar-Beiny, S.M. Gotham, W.R. Paterson, P.J. Fryer, The Effect of Reynolds Number and Fluid Temperature in Whey Protein Fouling, J. Food Eng. 19 (1993) 119139.

[12] A.J. Karabelas, S.G. Yiantsios, B. Thonon, J.M. Grillot, Liquid-side Fouling of Heat exchangers. An Integrated R\&D Approach for Conventional and Novel Designs, Appl. Therm. Eng. 17 (1997) 727-737. doi:http://dx.doi.org/10.1016/S1359-4311(96)00072-5.

[13] B. Bansal, X.D. Chen, A Critical Review of Milk Fouling in Heat Exchangers, Compr. Rev. Food Sci. Food Saf. 5 (2006) 27-33.

[14] M. Khaldi, P. Blanpain-Avet, R. Guérin, G. Ronse, L. Bouvier, C. André, S. Bornaz, T. Croguennec, R. Jeantet, G. Delaplace, Effect of Calcium Content and Flow Regime on Whey Protein Fouling and Cleaning in a Plate Heat Exchanger, J. Food Eng. 147 (2015) 68-78. 
[15] E. Sadeghinezhad, S.N. Kazi, M. Dahari, M.R. Safaei, R. Sadri, A. Badarudin, A Comprehensive Review of Milk Fouling on Heated Surfaces, Crit. Rev. Food Sci. Nutr. 12 (2014) 1724-1743.

[16] M. Khaldi, T. Croguennec, C. André, G. Ronse, M. Jimenez, S. Bellayer, P. BlanpainAvet, L. Bouvier, T. Six, S. Bornaz, Effect of the calcium/protein molar ratio on $\beta$ lactoglobulin denaturation kinetics and fouling phenomena, Int. Dairy J. 78 (2018) 1-10.

[17] R. Rosmaninho, O. Santos, T. Nylander, M. Paulsson, M. Beuf, T. Benezech, S. Yiantsios, N. Andritsos, A. Karabelas, G. Rizzo, H. Muller-Steinhagen, L.F. Melo, Modified Stainless Steel Surfaces Targeted to Reduce Fouling - Evaluation of Fouling by Milk Components, J. Food Eng. $80 \quad$ (2007) 1176-1187. doi:http://dx.doi.org/10.1016/j.jfoodeng.2006.09.008.

[18] J.A. Barish, J.M. Goddard, Anti-fouling Surface Modified Stainless Steel for Food Processing, Food Bioprod. Process. $91 \quad$ (2013) 352-361. doi:http://dx.doi.org/10.1016/j.fbp.2013.01.003.

[19] C. Boxler, W. Augustin, S. Scholl, Influence of Surface Modification on the Composition of a Calcium Phosphate-Rich Whey Protein Deposit in a Plate Heat Exchanger, Dairy Sci. Technol. 94 (2013) 17-31.

[20] J. Piepiorka-Stepuk, K. Tandecka, M. Jakubowski, An Analysis of Milk Fouling Formed During Heat Treatment On a Stainless Steel Surface with Different Degrees of Roughness, Czek J. Food Sci. 34 (2016) 271-279.

[21] S. Zouaghi, T. Six, S. Bellayer, S. Moradi, S.G. Hatzikiriakos, T. Dargent, V. Thomy, Y. Coffinier, C. André, G. Delaplace, M. Jimenez, Antifouling Biomimetic Liquid-Infused Stainless Steel: Application to Dairy Industrial Processing, ACS Appl. Mater. Interfaces. 9 (2017) 26565-26573. doi:10.1021/acsami.7b06709. 
[22] W. Norde, D. Gage, Interaction of Bovine Serum Albumine and Human Blood Plasma with PEO-Tethered Surfaces: Influence of PEO Cain Lenght, Grafting Density, and Temperature, Langmuir. 20 (2004) 4162-4167.

[23] V. Kumar, J. Pulpytel, G. Guidetti, H. Rauscher, F. Rossi, F. Arefi-Khonsari, Amphiphilic Copolymer Coatings via Plasma Polymerization Process: Switching and Anti-Biofouling Characteristics, Plasma Process. Polym. 8 (2011) 373-385.

[24] F. Khalil, E. Franzmann, J. Ramcke, O. Dakischew, K.S. Lips, A. Reinhardt, P. Heisig, W. Maison, Biomimetic PEG-Catecholates for Stabile Antifouling Coatings on Metal Surfaces: Applications on TiO2 and Stainless Steel, Colloids Surfaces B Biointerfaces. 117 (2014) 185-192. doi:http://dx.doi.org/10.1016/j.colsurfb.2014.02.022.

[25] N. MacCallum, C. Howell, P. Kim, D. Sun, R. Friedlander, J. Ranisau, O. Ahanotu, J.J. Lin, A. Vena, B. Hatton, T. Wong, J. Aizenberg, Liquid-Infused Silicone as a BiofoulingFree Medical Material, ACS Biomater. Sci. Eng. 1 (2014) 43-51.

[26] C.S. Gudipati, C.M. Greenleaf, J.A. Johnson, P. Prayongpan, K.L. Wooley, Hyperbranched Fluoropolymer and Linear Poly(ehtylene glycol) based Amphiphilic Crosslinked Networks as Efficient Antifouling Coatings: An Insight into the Surface Compositions, Topographies and Morphologies, J. Polym. Sci. Part A Polym. Chem. 42 (2004) 6193-6208.

[27] L. Xie, F. Hong, C. He, C. Ma, J. Liu, G. Zhang, C. Wu, Coatings with a Self-Generating Hydrogel Surface for Antifouling, Polymer (Guildf). 52 (2011) 3738-3744.

[28] W.J. Yang, K.-G. Neoh, E.-T. Kang, S.L.-M. Teo, D. Rittschof, Polymer Brush Coatings for Combating Marine Biofouling, Prog. Polym. Sci. 39 (2014) 1017-1042. doi:http://dx.doi.org/10.1016/j.progpolymsci.2014.02.002.

[29] R.B. Bodkhe, S.J. Stafslien, J. Daniels, N. Cilz, A.J. Muelhberg, S.E.M. Thompson, M.E. 
Callow, J.A. Callow, D.C. Webster, Zwitterionic Siloxane-Polyurethane Fouling-Release Coatings, Prog. Org. Coatings. $\quad 78 \quad$ (2015) 369-380. doi:http://dx.doi.org/10.1016/j.porgcoat.2014.07.011.

[30] R. Mùgica-Vidal, F. Alba-Elias, E. Sainz-Garcia, J. Ordieres-Meré, Atmospheric Plasma Polymerization of Hydrophobic and Wear-resistant Coatings on Glass Substrates, Surf. Coat. Technol. 259 (2014) 374-385.

[31] E. Sainz-García, F. Alba-Elías, R. Múgica-Vidal, M. Pantoja-Ruiz, Promotion of tribological and hydrophobic properties of a coating on TPE substrates by atmospheric plasma-polymerization, Appl. Surf. Sci. $371 \quad$ (2016) 50-60. doi:http://dx.doi.org/10.1016/j.apsusc.2016.02.186.

[32] R. Múgica-Vidal, F. Alba-Elías, E. Sainz-García, A. González-Marcos, Reducing friction on glass substrates by atmospheric plasma-polymerization of APTES, Surf. Coatings Technol. 309 (2017) 1062-1071. doi:http://dx.doi.org/10.1016/j.surfcoat.2016.10.030.

[33] L. Wang, Y. Wang, X.G. Sun, J.Q. He, Z.Y. Pan, Y. Zhou, P.L. Wu, Influence of pores on the thermal insulation behavior of thermal barrier coatings prepared by atmospheric plasma $\quad$ spray, $\quad$ Mater. $\quad$ Des. $32 \quad$ (2011) doi:http://dx.doi.org/10.1016/j.matdes.2010.06.040.

[34] C. Regula, J. Ihde, A. Keil, R. Wilken, A. Hartwig, U. Lommatzcsh, Influence of PreTreatment on the Adhesion and Protective Properties of Plasma Polymer Films Deposited by an Atmospheric Pressure Plasma Jet on Ag and Cu Surfaces, in: ISPC19, 2009.

[35] U. Lommatzcsh, J. Ihde, Plasma Polymerization of HMDSO with an Atmospheric Pressure Plasma jet for Corrosion Protection of Aluminium and Low-Adhesion Surfaces, Plasma Process. Polym. 6 (2009) 642-648.

[36] C.E. Nwankire, M. Ardhaoui, D.P. Dowling, The Effect of Plasma-Polymerised Silicon 
Hybride-Rich Polyhydrogenmethylsiloxane on the Adhesion of Silicon Elastomers, Polym. Int. 58 (2009) 996-1001.

[37] S. Bhatt, J. Pulpytel, S. Mori, M. Mirshahi, F. Arefi-Khonsari, Cell Repellent Coatings Developed by an Open Air Atmospheric Pressure Non-Equilibrium Argon Plasma for Biomedical Applications, Plasma Process. Polym. 11 (2014) 24-36.

[38] B. Nisol, G. Oldenhove, N. Preyat, D. Monteyne, M. Moser, D. Perez-Morga, F. Reniers, Atmospheric Plasma Synthesized PEG Coatings: Non-Fouling Biomaterials Showing Protein and Cell Repulsion, Surf. Coat. Technol. 252 (2014) 126-133.

[39] G. Al-ogaili, M. Jimenez, S. Bellayer, N. Nuns, A. Allion, A. Beaurain, G. Ronse, G. Delaplace, M. Traisnel, Development anti-dairy fouling surface of 316L 2B stainless steel by atmospheric pressure plasma treatment, in: Plasma Sci. Held with 2014 IEEE Int. Conf. High-Power Part. Beams (BEAMS), 2014 IEEE 41st Int. Conf., IEEE, 2014: p. 1.

[40] R. Szabová, L. Cernakova, M. Wolfová, M. Cernak, Coating of TiO2 nanoparticles on the plasma activated polypropylene fibers, Acta Chim. Slovaca. 2 (2009) 70-76.

[41] D.H. Kaelble, Dispersion-Polar Surface Tension Properties of Organic Solids, J. Adhes. 2 (1970) 66-81. doi:10.1080/0021846708544582.

[42] H.E. Indyk, S. Hart, T. Meerkerk, B.D. Gill, D.C. Woollard, The $\beta$-lactoglobulin content of bovine milk: Development and application of a biosensor immunoassay, Int. Dairy J. 73 (2017) 68-73. doi:https://doi.org/10.1016/j.idairyj.2017.05.010.

[43] S. Tang, O.-J. Kwon, N. Lu, H.-S. Choi, Surface Characteristics of AISI 316L Stainless Steel After Atmospheric Pressure Plasma Treatment, Surf. Coat. Technol. 195 (2005) 298306.

[44] O. Santos, T. Nylander, R. Rosmaninho, G. Rizzo, S. Yiantsios, N. Andritsos, A. Karabelas, H. Muller-Steinhagen, L. Melo, L. Boulange-Petermann, C. Gabet, A. Braem, 
C. Tragardh, M. Paulsson, Modified Stainless Steel Surfaces Targeted to Reduce Fouling Surface Characterization, J. Food $\quad$ Eng. $64 \quad$ (2004) 63-79. doi:http://dx.doi.org/10.1016/j.jfoodeng.2003.09.013.

[45] V. Oldani, R. del Negro, C.L. Bianchi, R. Suriano, S. Turri, C. Pirola, B. Sacchi, Surface Properties and Anti-fouling Assessment of Coatings Obtained from Perfluoropolyethers and Ceramic Oxides Nanopowders Deposited on Stainless Steel, J. Fluor. Chem. 180 (2015) 7-14.

[46] M. Beuf, G. Rizzo, J.C. Leuliet, H. Müller-Steinhagen, S. Yiantsios, A. Karabelas, T. Benezech, Fouling and Cleaning of Modified Stainless Steel Plate Heat Exchanger Processing Milk Products, in: P. Watkinson, H. Müller-Steinhagen, M. Reza Malayeri (Eds.), Heat Exch. Fouling Clean. Fundam. Appl., Kloster Isree, Germany, 2003.

[47] U. Lommatzsch, J. Ihde, Plasma Polymerization of HMDSO with an Atmospheric Pressure Plasma Jet for Corrosion Protection of Aluminum and Low-Adhesion Surfaces, Plasma Process. Polym. 6 (2009) 642-648. doi:10.1002/ppap.200900032.

[48] E. Bormashenko, Young, Boruvka-Neumann, Wenzel and Cassie-Baxter equations as the transversality conditions for the variational problem of wetting, Colloids Surfaces A Physicochem. $\quad$ Eng. Asp. $345 \quad$ (2009) 163-165. doi:http://dx.doi.org/10.1016/j.colsurfa.2009.04.054.

[49] S. Zouaghi, T. Six, N. Nuns, P. Simon, S. Bellayer, S. Moradi, S.G. Hatzikiriakos, C. Andre, G. Delaplace, M. Jimenez, Influence of stainless steel surface properties on whey protein fouling under industrial processing conditions, J. Food Eng. 228 (2018) 38-49. doi:https://doi.org/10.1016/j.jfoodeng.2018.02.009.

[50] M.C. Biesinger, B.P. Payne, A.P. Grosvenor, L.W.M. Lau, A.R. Gerson, R.S.C. Smart, Resolving Surface Chemical States in XPS Analysis of First Row Transition Metals, 
Oxides and Hydroxides: Cr, Mn, Fe, Co and Ni, Appl. Surf. Sci. 257 (2011) 2717-2730.

[51] T. Sakiyama, K. Tanino, M. Urakawa, K. Imamura, T. Takahashi, T. Nagai, K. Nakanishi, Adsorption Characteristics of Tryptic Fragments of Bovine Beta-Lactoglobulin on a Stainless Steel Surface, J. Biosci. Bioeng. 88 (1999) 536-541. doi:http://dx.doi.org/10.1016/S1389-1723(00)87672-0.

[52] C.D. Wagner, A. V Naumkin, A. Kraut-Vass, J.W. Allison, C.J. Powell, J.R. Rumble Jr, NIST standard reference database 20, Version 3.4 (Web version), Natl. Inst. Stand. Technol. Gaithersburg, MD. 20899 (2003).

[53] G. Beamson, D. Briggs, High Resolution XPS of Organic Polymers: The Scienta ESCA300 Database (Beamson, G.; Briggs, D.), J. Chem. Educ. 70 (1993) A25. doi:10.1021/ed070pA25.5.

[54] E.F. Voronin, V.A. Tertykh, V.M. Ogenko, A.A. Chuiko, Electron-acceptor properties of silicon atoms in surface chemical compounds, Theor. Exp. Chem. 14 (1978) 495-500. doi:10.1007/BF01004353.

[55] C. Boxler, W. Augustin, S. Scholl, Fouling of Milk Components on DLC Coated Surfaces at Pasteurization and UHT Temperatures, Food Bioprod. Process. 91 (2013) 336-347. doi:http://dx.doi.org/10.1016/j.fbp.2012.11.012.

[56] G. Wirtanen, H. Ahola, T. Mattila-Sandholm, Evaluation of cleaning procedures in elimination of biofilm from stainless steel surfaces in open process equipment, Food Bioprod. Process. Trans. Inst. Chem. Eng. Part C. (1995).

[57] S.H. Flint, J.D. Brooks, P.J. Bremer, Properties of the stainless steel substrate, influencing the adhesion of thermo-resistant streptococci, J. Food Eng. 43 (2000) 235-242. doi:https://doi.org/10.1016/S0260-8774(99)00157-0. 
Highlights for Atmospheric Plasma Spraying of Silane-Based Coatings Targeting Whey Protein Fouling and Bacterial Adhesion Management.

- Among manufacturing conditions, precursor flow rate highly impacts coating topography.

- Silane-based coatings efficiently decrease whey protein isothermal fouling.

- A Si-O-Si-rich and nanotextured surface is an asset against protein fouling and bacterial adhesion. 


\section{Graphical abstract}

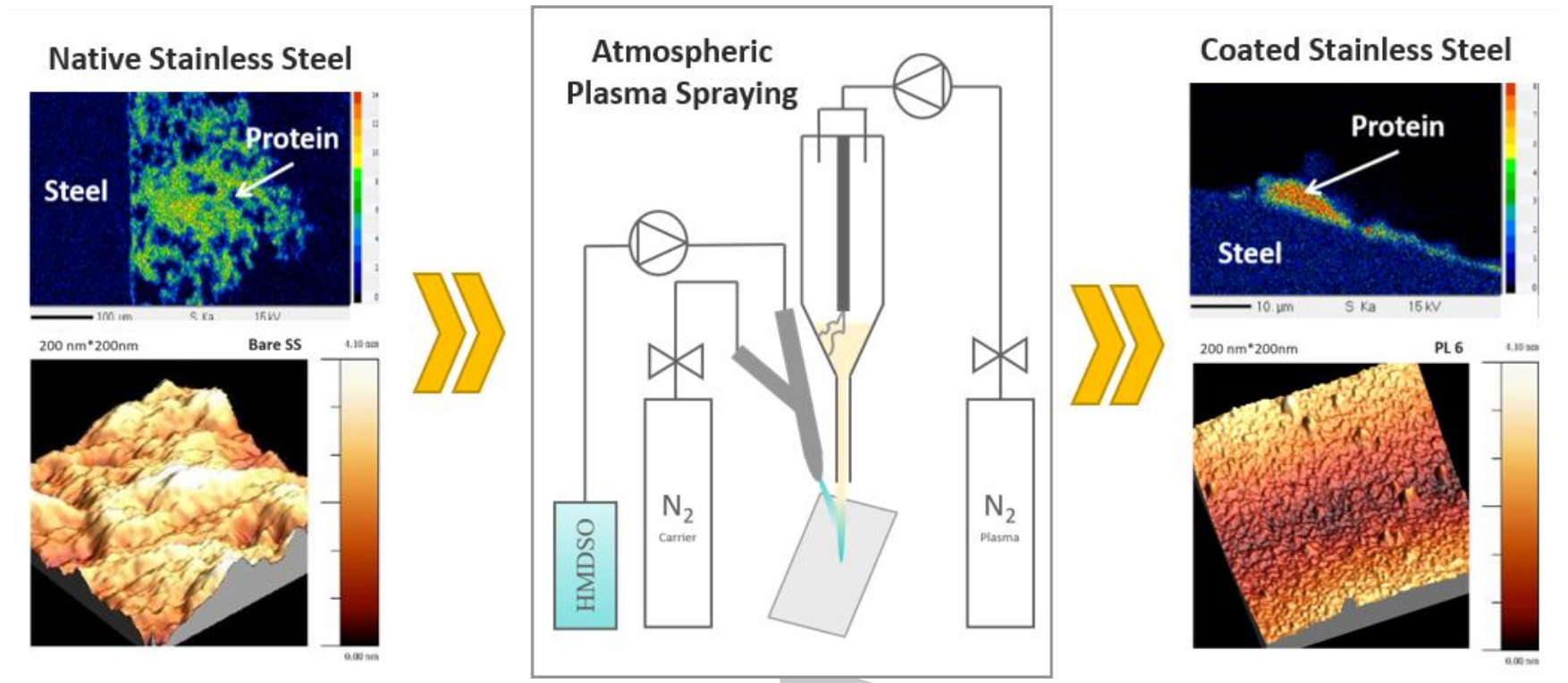

